\title{
latrogenic opioid dependence is endemic and legal: Genetic addiction risk score (GARS) with electrotherapy a paradigm shift in pain treatment programs
}

\author{
Kenneth Blum ${ }^{1,2,3,4,5,6,7,8,9,10,11,12 \#}$, David Han ${ }^{13}$, Marlene Oscar-Berman ${ }^{14}$, Gary Reinl ${ }^{2,15}$ \\ Nicholas DiNubile ${ }^{2,3}$, Margaret A. Madigan ${ }^{4,12}$, Anish Bajaj $^{5}$, Bernard William Downs ${ }^{4,12}$, \\ John Giordano ${ }^{6}$, Wayne Westcott ${ }^{16}$, Leonard Smith $^{17}$, Eric R. Braverman ${ }^{1,5}$, Kristina Dushaj ${ }^{5}$, \\ Mary Hauser ${ }^{7}$, Thomas Simpatico ${ }^{8}$, Thomas McLaughlin ${ }^{18}$, Joan Borsten ${ }^{9}$, Debmayla Barh ${ }^{10}$ \\ ${ }^{1}$ Department of Psychiatry, College of Medicine \& McKnight Brain Institute, University of Florida, Gainesville, USA; \\ \#Corresponding Author: drd2gene@,gmail.com \\ ${ }^{2}$ Electronic Waveform Lab, Department of Pain Research, Huntington Beach, USA \\ ${ }^{3}$ Department of Orthopedic Surgery, Hospital of the University of Pennsylvania, Philadelphia, USA \\ ${ }^{4}$ Department of Molecular Nutrition, Impact Genomics, Inc., Austin, USA \\ ${ }^{5}$ Department of Executive Health, Path Research Foundation NY, New York, USA \\ ${ }^{6}$ Department of Holistic Medicine and Pain Track, National Institute for Holistic Addiction Studies, North Miami Beach, USA \\ ${ }^{7}$ Dominion Diagnostics LLC, North Kingstown, USA \\ ${ }^{8}$ Department of Psychiatry, Human Integrated Services Unit of Vermont Center for Clinical \& Translational Science, University of \\ Vermont College of Medicine, Burlington, USA \\ ${ }^{9}$ Department of Addiction Research \& Therapy, Malibu Beach Recovery Center, Malibu Beach, USA \\ ${ }^{10}$ Centre for Genomics and Applied Gene Technology, Institute of Integrative Omics and Applied Biotechnology (IIOAB), Nonakuri, \\ Purba Medinipur, India \\ ${ }^{11}$ Genomics Health Care, Portland, USA \\ ${ }^{12}$ Igene LLC, Austin, USA \\ ${ }^{13}$ Department of Management Science and Statistics, The University of Texas at San Antonio, San Antonio, USA \\ ${ }^{14}$ Department of Psychiatry, Anatomy \& Neurobiology, Boston VA and Boston University School of Medicine, Boston, USA \\ ${ }^{15}$ Nautilus Inc., Vancouver, USA \\ ${ }^{16}$ Department of Exercise Science, Quincy College, Quincy, USA \\ ${ }^{17}$ Department of Surgery, University of Miami School of Medicine, Miami, USA \\ ${ }^{18}$ Center for Psychiatric Medicine, North Andover, USA
}

Received 19 September 2013; revised 25 October 2013; accepted 1 November 2013

Copyright (C) 2013 Kenneth Blum et al. This is an open access article distributed under the Creative Commons Attribution License, which permits unrestricted use, distribution, and reproduction in any medium, provided the original work is properly cited.

\section{ABSTRACT}

The mounting endemic of prescription iatrogenic opioid dependence in pain patients provoked this treatise about an alternative method that can be used to treat pain, improve function and reduce the risk of opioid dependence. It is

"Conflict of interest: Kenneth Blum, PhD, DHL, Nicholas DiNubile, MD, David Han, PhD and Gary Reinl are paid consultants for Electronic Waveform Lab, Huntington Beach, California. Kenneth Blum, and B. William Downs, B.SC., have interest in Impact Genomics, Inc. Mary Houser; MSc is Vice President of Dominion Diagnostics, LLC, North Kingstown, Rhode Island, a commercial partner of IGENE for GARS. Kenneth Blum and Thomas Simpatico. MD are members of the scientific advisory board member of Dominion Diagnostics. All other authors do not disclose any conflict of interest.

Authors' contributions: All authors equally contributed to this article. well known that as well as the side effects reported for chronic opioid therapy, genetically predisposed individuals are at risk for opioid dependence. We propose the use of the Genetic Addiction Risk Score (GARS) assessment to identify patients early in treatment who should avoid narcotic pain medications. Primarily, this review will be an exploration of the mechanisms of action of an electrotherapeutic alternative to narcotic treatment that can be used to augment tissue healing and reduce the pain associated with human injuries and neuropathies. This particular electrotherapeutic device was developed at the Electronic Waveform Laboratory in Huntington Beach, California and is called the $\mathrm{H}$ - 
Wave $^{\circledR}$ device. The primary effect of the H-Wave ${ }^{\circledR}$ device is stimulation (HWDS) of small diameter fibers of "red-slow-twitch" skeletal muscle. Mechanisms of action of HWDS have been investigated in both animal and human studies. They include edema reduction, induction of nitric oxide dependent augmented microcirculation and angiogenesis, small muscle contraction that eliminates trans-capillary fluid shifts, reducing the painful effects of tetanizing fatigue and gradual loading of healing injured muscle tissue that helps repair and remodeling. A recent metaanalysis found a moderate-to-strong-positive effect of the HWDS in providing pain relief, reducing the requirement for pain medication, with the most robust effect being increased functionality. We are proposing that GARS can be used to identify those at risk of developing opioid dependence and that the need for opioid analgesia can be reduced by use of this electro therapeutic alternative to opioid analgesia in the treatment of pain and injuries.

Keywords: Microcirculation; Angiogenesis; Analgesic Therapy; Electrical Device Stimulation; Tissue Loading; Remodeling; Genetic Addiction Risk Score (GARS); Reward Deficiency Syndrome (RDS)

\section{INTRODUCTION}

\subsection{Opioid Prescription Endemic}

The extent of the opioid prescription epidemic in the USA was revealed in a weekly Morbidity and Mortality Report from the Center for Disease Control entitled "Prescription Drug Overdoses - a US Epidemic" at the beginning of 2012. According to the report there were about 27,000 unintentional iatrogenic drug overdose deaths that occurred in 2007 in the United States [1]. Over the past 10 years in an attempt to treat patient pain better, practitioners have increased the use of prescription opioid analgesics $>600 \%$ [2]. By 2010, opioid analgesics, such as hydrocodone, methadone and oxycodone, were involved in three quarters $(16,651)$ pharmaceutical overdose deaths [3]. Five million out of the nine million people, who use opioids long term [3], report use without medical need or a prescription (non-medical use in the past month) [4].

The breakdown of prescription overdoses is as follows: 1) $80 \%$ of all opioids are prescribed by a single clinician low doses $(<100 \mathrm{mg}$ morphine equivalent dose per day) $[5,6]$, accounting for about $20 \%$ of all prescription drug overdoses; 2) $10 \%$ of patients are prescribed high doses
( $\geq 100 \mathrm{mg}$ morphine equivalent dose per day) by single physicians accounting for an estimated $40 \%$ of prescription opioid overdoses [2,7] and 3) $10 \%$ of patients seek care from multiple clinicians and are prescribed high daily doses, accounting for another $40 \%$ of opioid overdoses [8].

These data suggest that prevention of opioid overdose deaths should focus on strategies that target a reduction in the availability of opioid medications. Electronic medical records have been initiated, and laws enacted to curb those who seek care from multiple doctors receive high doses, and are likely to be involved in drug diversion. Other approaches that could prevent these opioid overdoses and the morbidity that accompanies opioid dependence are the focuses of this paper. They are genetic testing for addiction liability and an alternative to narcotic analgesic treatment for pain. An alternative to pharmaceutical pain treatment is electrotherapy.

\subsection{Characteristics of Electrotherapy}

The use of electrotherapy for neuropathic pain is wellknown [9]. One device and program known as $\mathrm{H}$-wave ${ }^{\mathbb{B}}$ electrical device stimulation (HWDS) is used clinically to expedite recovery from soft tissue injuries. A number of published studies have shown that HWDS produces a physiological response to tissue injuries and neuropathies [9-27]. Research that involves both animal models and humans has indicated that HWDS affects tissue healing in a positive manner and has analgesic properties. HWDS utilizes direct current electrical stimulation of the skeletal muscle surface. Low voltages and low stimulation frequencies are employed in this therapy.

A number of physiological mechanisms of action (MOA) of HWDS have been investigated recently in animals. Certainty of these mechanisms may have profound effects on the overall elements related to the healing process. The physiological responses to HWDS resulting in improvements, in tissue circulation, are due to the following MOA:

1) Muscle contraction of smooth and skeletal muscle (red, slow twitch) fibers via low frequency $(1-2 \mathrm{~Hz})$ stimulation causes loading of tissue while maintaining the low muscle force tension characteristic of being nontetanizing and non-fatiguing [10].

2) Arteriolar vasodilation accompanies HWDS and is due to a nitric-oxide mechanism demonstrated in rat studies [12].

3) Increase in new blood vessels angiogenesis following repetitive stimulation demonstrated bromouridine staining in rats [14].

4) Small smooth muscle fibers within the lymphatic vessels are directly and specifically stimulated ultimately leading to fluid shifts that reduce edema and protein clearance [22]. 


\subsection{Tissue Loading Effect on Cellular Matrix and Genetic Expression}

An important concept in orthopedic medicine and as such healing of tissue, especially bone, fibrous and skeletal muscle, is the acceleration of healing through loading $[28,29]$. It is noteworthy that even now when sophisticated new approaches such as the use of cytokines, cell transplants, and gene therapy have shown promise, none offer greater benefits than the loading of healing tissues [30]. Mak et al. [27] in a detailed review, have suggested that (once the injury reaches stability) loading may promote healing through a number of mechanisms involved in the healing process as it specifically relates to endurance and muscle recovery. Certainly the importance of loading on bone, fibrous tissue and muscle healing has been the subject of controversy since Nicholas Andre' and Locus-Championniere, taught that early controlled activity promotes healing and restores functionality [30]. Other authorities argued against this view and suggested that absolute rest allows healing to proceed at the maximum pace and that loading may cause harm and inflammation thereby disrupting the natural healing process [31]. However, even as far back as 1892, Julius Wolf suggested that loading of bone may indeed cause changes in their structure, according to mathematical principles described as "Wolff's law" [31].

"Recent investigations have provided insight into the mechanisms responsible for Wolff's law and have shown that connective tissues other than bone also respond to changes in loading. These studies have shown that tissue-loading influences cell shape, gene expression, and synthesizing and proliferating functions. Bone, tendon, ligament, and joint capsule respond initially to loading by a mechanism of cellular detection of tissue strains, (these are) followed by modification of the tissue" [31].

Briefly, it is well known that the cells may detect tissue tension directly, or indirectly, through alterations in the cellular matrix, through deformation of the tissue. It is especially compelling that stretching or compression of mesenchymal cells alters the alignment of the cytoskeletal elements. These changes in cell shape induce gene expression and changes synthesis of matrix molecules and prostaglandins [31-40]. Eliasson et al. [40] evaluated gene expression following mechanical loading in rat Achilles tendon and found that, during the healing process, specific genes such as TNF-alpha transforming growth factor-beta 1 and procollagens 1 and 111 were down-regulated in loaded callus tissue at day three. However, by days 14 and 21, pro-collagen 1, cartilage oligomeric matrix protein, tenascin-C, tenomodulin, and scleraxis were all more expressed in loaded calluses. In the late phase of healing, tendon-specific genes (scleraxis and tenomodulin) were upregulated with loading, and the healing tissue might to some extent represent regenera- tion rather than a scar. Moreover, while intact tendons adapt slowly to changes in mechanical loading, the effect of mechanical loading on healing tendons or its absence is dramatic. The persistence of the response to a single episode of loading is unknown. The hypothesis that tissue has a "memory" of loading episodes, led to the idea that improved healing may be elicited by short loadings. Their animal findings indicated that information from a certain loading type and level once received by the tissue is "memorized" and the response lasts for many hours. This suggests that early short loading episodes might allow patients a better outcome following, for example, a ruptured Achilles tendon [41].

Healing back-pain through loading of the large muscle groups has been established long ago as the 1980's [42]. The pathophysiology of the motion segment of the spine is influenced by several factors. Loading for various postures and exercises, including those at work has been successfully measured and delineated. The effect of various external factors has been measured, and nutriational pathways to the disc have been established. The body's pain reducing-enkephalins are increased by activation of large muscle groups. Nachemson [41] suggests that early diagnosis and early mobilization of the patient should be of benefit, and that long term bed rest and inactivity must be prevented. Similar to others [30] Nachemson [43] in the 1970's also believed that absolute rest was an essential component to the healing of back pain. A number of recent experiments have adequately resolved this controversy [31].

\subsection{Cellular and Physiological Principles of Loading}

It is well known that deformation of the cellular matrix can alter the macro-molecular organization, fluid flow (NO-dependent), streaming currents, pressure gradients, or electrical fields [40] and these matrix alterations certainly can influence cell function [40,44-48]. It is noteworthy that loading of a tissue can also alter the flow of nutrients and metabolites by affecting vascular perfusion and diffusion through the matrix $[49,50]$. The mechanisms of skeletal muscle response to changes in loading differ in some respects from those of bone and fibrous tissue because of the innervated muscle cells or myofibers, and to a lesser extent, an extracellular matrix [51]. Unlike connective-tissue cells, myofibers respond primarily to persistent changes in activity with alterations in cell structure, volume, and function. The importance here is that muscle cells respond to both passive stretching and active contraction [51]. There is no doubt that maintenance of normal muscle structure requires a minimal level of repetitive loading. Depending on variables such as age and gender, a low level of activity can lead to atrophy and decreases in muscle tissue organization and 
strength, while activity above the minimal level could lead to increases in muscle strength and mass [52].

We cautiously suggest that HWDS may be a valuable modality for the "loading" of bone to assist in the healing of osteoporosis and/or osteopenia related fractures. The importance of this potential is supported by public health and economic statistics about fractures from the National Institute of Arthritis and Musculoskeletal, and Skin Diseases [52] reported as follows:

"Osteoporosis is a major public health threat for 44 million Americans, 68 percent of whom are women; in the United States today, 10 million individuals already have osteoporosis and 34 million more have low bone mass, placing them at increased risk for this disease; one out of every two women and one in four men age 50 and older will have an osteoporosis-related fracture in their lifetime; more than 2 million American men suffer from osteoporosis, and millions more are at risk. Each year, 80,000 men have a hip fracture and one-third of these men die within a year; Osteoporosis can strike at any age; Osteoporosis is responsible for more than 1.5 million fractures annually, including approximately 300,000 hip fractures, 700,000 vertebral fractures, 250,000 wrist fractures, and more than 300,000 fractures at other sites; based on figures from hospitals and nursing homes, the estimated national direct expenditures for osteoporosis and related fractures total $\$ 14$ billion each year" [53].

Interestingly, immobilization of a limb in a cast or traction for a prolonged period of time causes the rate of bone resorption to exceed that of bone formation $[54,55]$ and subsequent loss of bone mass. Specifically, Goodship et al. [56] found that, without weight bearing, bone mass declines to less than half the normal value after 12 weeks. Conversely, persistent bone loading causes bone formation to exceed bone resorption and can result in increases in density, volume and strength [55,57]. This being the case it would be prudent to enhance treatment outcomes by understanding the risk for bone loss in the face of non-loading especially during immobilization periods are essential for normal skeletal growth and maintenance of skeletal structural and mechanical integrity relies on adequate Vitamin D and calcium. While reduced intake may result in osteoporosis and reduced bone mass, osteomalacia may be the result of severe and chronic vitamin D deficiency [58]. The vitamin D recaptor gene polymorphisms were investigated first, as possible determinants of bone mass loss and fracture risk, because of the importance of vitamin D in bone homeostasis [52]. Most of the epidemiological studies showed that the BAt haplotype, from BsmI, ApaI and TaqI polymorphisms in VDR, are associated with a lower bone mineral density in women and a higher risk of osteoporotic fractures. Knowledge of this risk may indicate that the level of loading may need to be adjusted up or down based on these gene polymorphisms [59]. There is also the likelihood that parathyroid levels may also play a significant role in bone resorption risk due to nonloading. Moreover, the plasma levels of Parathyroid Hormone have been tied to not only osteoporosis but to dementia and stress, which could also influence the bone-healing outcome [60].

Based on unpublished very preliminary information on only one patient, we found that $\mathrm{H}$-Wave induced bone loading over a 4-month period increased bone density via $\mathrm{X}$-ray. We must await additional subjects to establish $\mathrm{H}$-Wave induced bone mass. In addition, in an unpublished review, a physician evaluation found that HWDS induced new bone growth seen on X-ray in another patient with a comminuted fracture of the tibia following 90 days of treatment. We do not know if, in this patient the healing process was so strong that new bone growth may have resulted without HWDS. The impetus to continue to evaluate HWDS in patients who have bone injury seems parsimonious.

It is noteworthy that, unlike other tissue, (with the exception of perhaps liver) bone is the only tissue that heals with its original tissue. In fact, bone as opposed to all other human tissue - especially tendon, muscle and ligaments - which heal, with scar tissue rather than the original tissue structure. Moreover, scar formation in these healing tissues can be modulated differently (qualitative and quantitative) depending on the healing environment and possibly genetics.

We hypothesize that potentially similar to muscle loading HWDS may reduce bone resorption via physiological responses and MOA. This is further supported by the suggestion of Burr et al. [52] that regular contraction of the muscles of an immobilized limb may decrease the rate of loss of bone.

Along similar lines, immobile dense fibrous tissues that normally resist (tendon, ligament, and joint capsule) alters matrix turnover, so that with time, matrix degradation exceeds formation. In terms of matrix metaloprotein rat studies reveal that in dental implants, localization and bone formation with osteocalcin were associated with high shear stress areas near the helical threads of loaded implants. The apical two-thirds of each unloaded bone implant showed fibrous tissue and extensive MMP-13 localization adjacent to the implant [58]. In agreement with estimated bone-implant contact ratios, between 14 and 21 days, a significantly higher contact ratio was demonstrated in the loaded group while a steady decrease in contact ratio occurred in the unloaded implant group [52]. Other studies by Akeson [59] that looked at limb immobilization, found that prolonged limb immobilization, especially after 6 weeks, may have increased collagen cross-linking and decreased collagen mass, decreased the glycosaminoglycan and water content, and changed the 
degree of orientation of the matrix collagen fibrils. Interestingly MRI studies have shown that HWDS causes beneficial fluid shifts as observed in magnetic resonance imaging studies which should impact this unwanted result [10].

Decreased loading also affects ligament, tendon and capsular insertions into bone. For example, decreased ligament loading due to immobilization usually produces more extensive changes in the periosteum type of insertion. With knee injuries prolonged immobilization causes bone resorption around the periphery of the cruciate ligament insertions, but only limited resorptive activity beneath the insertion site and in the zone of fibrocartilage [61]. In fact, in animal experiments it has been shown that immobilization after 6 - 8 weeks requires loading of the ligament insertion site for as long as one year to obtain healing [62]. Furthermore, repetitive loading can increase the strength, size, matrix organization, and collagen content of tendons, ligaments and their insertions into bones. In support of this statement Slack et al. [62] showed that tension to cultured tendons increased protein and DNA synthesis. Other studies revealed that intensive exercise training, in swine, augmented extensor tendon strength, collagen concentration and weight [63]. The same researchers also found that in vitro rabbits showed that localized increased loading alone causes adaptation of dense fibrous tissue [64].

\subsection{Nitric Oxide and Muscle Activation}

Nitric oxide (NO) known as the "endothelium-derived relaxing factor", or "EDRF", is biosynthesized endogenously and NO production plays a major role in the physiology of circulation $[65,66]$. Deficiency of this putative neurotransmitter has been linked to a number of diseases/disorders of the circulatory system [67]. NO is synthesized in normal muscle fibers by the neuronal NO and the endothelial $\mathrm{NO}$ isoforms of nitric oxide synthase NO. NO contributes to the regulation of several processes such as excitation-contraction coupling and mitochondrial respiration both very important in loading [68]. In experiments by Pye et al. [68] muscle fibers were isolated from the flexor digitorum brevis muscle of mice, and intracellular NO production was visualized in realtime using the fluorescent NO probe 4-amino-5-methylamino-2',7'-difluorofluorescein diacetate (DAF-FM DA). Electrically stimulated contractions in isolated fibers increased the rate of change in DAF-FM fluorescence by approximately $48 \%$ compared to non-stimulated fibers $(\mathrm{P}<0.05)$. The rate of change in DAF-FM fluorescence in the stimulated fibers returned to control values by $5 \mathrm{~min}$ after contractions. Treatment of isolated fibers with the NO synthase inhibitors NG-nitro-L-arginine methyl ester hydrochloride (L-NAME) or NGmonomethyl-L-arginine (L-NMMA) reduced the in- crease in DAF-FM fluorescence observed in response to contractions of untreated fibers. Since electrical stimulation causes an increase in muscle NO (during loading), it is feasible that the Smith et al. [13] study showing a NO dependent increase in microcirculation of the rat by HWDS together with the work of Pye et al. [68] may provide the MOA that can explain this observed phenomena.

The non-tetanizing and non-fatiguing properties of HWDS, unlike other electro-therapeutic devices and or drugs, may be most beneficial in augmenting skeletal muscle loading induced tissue blood flow linked to an increase in NO production during periods of healing $[13,14]$. It is noteworthy that there are a number of pharmaceuticals that induce a NO dependent vasodilatation, for the treatment of circulatory dysfunction; however, their positive therapeutic effects have been clouded by moderate to severe adverse reactions in patients [69]. The mechanism of such a benefit as HWDS induced NO production, may reside in the importance of $\mathrm{NO}$ in cell communication and the inflammatory process a necessary repair phenomena that should not be interrupted during early stages of tissue repair [69]. An example is that NO elicits functional MMP-13 protein tyrosine nitration during wound repair [70]. The beneficial effects of NO on tissue repair may be attributed to its functional influences on angiogenesis [22,71], inflammation, cell proliferation, matrix deposition, and remodeling [10,11, 72].

\subsection{Angiogenesis and Musculoskeletal Healing}

Angiogenesis, new blood vessel formation, takes place following a disturbance in the luminal side of blood vessel endothelium. Increased stretch/wall tension/shear stress initiated by increased blood flow velocity, capillary hematocrit or the release of NO, prostaglandins, growth factors or other humoral agents may damage luminal endothelium and/or their basement membrane [24,73]. Angiogenesis, is part of normal physiology examples including, female reproductive organs, skeletal and cardiac muscle due to increased training and as a response to hypoxia and increased altitude [73].

The mechanisms responsible for either the acute, shortterm or the long-term effects of HWDS on the microcirculation may involve angiogenesis [24]. In fact, in rat studies we have found that bromouridine staining demonstrated increased staining for new blood vessels in chronically stimulated hind limb of rats following HWDS [24]. We suggest that this induction of angiogenesis is due to the chronic vasodilatation associated with chronic loading of the muscle through non-tetanizing and nonfatiguing stimulation. Moreover, alterations in wall tension produced by vasodilation or changes in microvas- 
cular wall shear stress appear to be stimuli for elaboration of new blood vessel formation [71]. Hudlicka investigated these mechanisms.

Hudlicka's [73] experiment exposed skeletal muscles to: 1) chronic electrical stimulations to increased activity; 2) various vasodilators to blood flow, long-term; 3) $\mathrm{CoCl}_{2}$ administration of to increase hematocrit also longterm; and 4) removal of agonist muscles effect long-term stretch. Electron microscopy with histochemical staining was used to visualize an increased capillary/fiber ratio, had occurred in every exposure but 3 ). An estimation of capillary proliferation was made by label indexing capillary-linked nuclei, for bromodeoxyuridine found capillary proliferation in 1). Capillary diameter increased, arterioles underwent transient widening and veinuoles did not change with chronic electrical stimulation. The velocity of red blood cells (Vrbc), capillary hematocrit, wall tension and calculated shear stress were increased compared to control muscles, by administration of the alpha 1-blocker prazosin. Longer sarcomeres caused initial concomitant stretch of capillaries in stretched muscles. Stretched muscles also caused decreased blood flow.

Hudlicka [73] showed that immunohistochemistry in stimulated or stretched muscles revealed increases in low molecular mass endothelial cell-stimulating angiogenic factor (ESAF) in 1), 2), and 4). There was no evidence of mRNA expression for the growth factor itself or basic fibroblast growth factor (bFGF). After administration of indomethacin or L-NNA, the involvement of NO and prostaglandins was demonstrated when BrdU was incurporated into capillary-linked nuclei in stimulated muscles. Thus, changes in the microcirculation leading to increased shear stress and/or capillary wall tension may, as observed in HWDS, induce proliferation of endothelial cells either directly, or by release of various humoral factors. This phenomenon is the subject of additional research (Figure 1).

\subsection{Protein Clearance and Cytokines in the Healing Process}

It is well known that, in healing, the tissue responses that can restore tissue integrity (structure and function) after injury result from complex humoral and specific vascular events [74]. Understanding the healing process, which includes inflammation, repair and remodeling, enables the clinician to treat the injury appropriately and systematically. The continuous process begins with the release of inflammatory mediators such as interleukin factors (regulated by polymorphisms of TNF-Alpha) and ends when remodeling of the repair tissue reaches a homeostatic state. It is at this time in the healing process that loading can positively affect tissue healing from the repair stage through the remodeling stage [75].
Multiple mechanisms are necessary to temporally restrict and direct the effects of potent mediators of immune reactions, inflammation, and tissue repair. Recent studies have implicated the protein alpha 2-macroglobulin (alpha 2M) as a mediator that regulates the activeity and distribution of many cytokines. These include platelet derived growth factor (PDGF), transforming growth factors-beta (TGFs-beta), tumor necrosis factoralpha (TNF-alpha), interleukin-6 (IL-6), inter-leukin-1 beta (IL-1 beta), nerve growth factor (NGF) and fibroblast growth factor (b-FGF) [75].

As early as 1985, Proctor et al. [76] suggested a change in the synthesis of one or several different cytokines might result in disease and represent either changes in their alpha 2M-receptor-mediated clearance/targeting mechanisms or in the production of alpha $2 \mathrm{M}$ "cytokine scavengers". Moreover, the "sequence identity" between the alpha 2M Receptor and the LDL-receptor related protein and provides a theoretical basis for interference with cytokine clearance by association of competing lipoprotein ligands with this cytokine clearance pathway. In addition, activated alpha $2 \mathrm{Ms}$ or enhancement of alpha 2M-receptor-dependent cytokine clearance might be novel strategies for preventing the harmful systemic or local effects of excess cytokines such as TGF-beta s and TNF-alpha in vivo.

"Fibronectin" found, in connective tissues (in blood) and most basement membranes are a group of immunochemically related glycoproteins that have an adhesive function. Distinct binding domains serve to mediate between collagen, cells like macrophages, fibrinogen, and fibroblasts, and/or certain glycosaminoglycans like heaprin. The "mononuclear phagocytic" system is comprised of macrophages and monocytes phagocytic cells. The monocytes attachment to gelatin-coated surfaces and gelatin-coated RBCs or latex particles attach to surfacebound monocytes. This adhesion is mediated by plasma fibronectin (Cig).

Protein clearance, as a natural step in the healing process, is a very complex phenomena and is not simply the milking action of the smooth musculature of the lymphatics. Thus, the ability to clear out unwanted elements is not based on simple mechanics. It is indeed chemical in nature. The strong affinity between fibrin and fibronectin is and may provide a mechanism for the recognition of fibrin-fibrinogen complexes and their subsequent clearance from the blood, on mononuclear phagocytes attached to fibronectin receptors [76]. Fibronectin bound to denatured or exposed collagen at sites of injury may lead to macrophage attachment and differentiation and probably plays an important role in wound organization and healing [77].

Unpublished preliminary data from the laboratory of Thomas Smith at Wake Forest University School of 


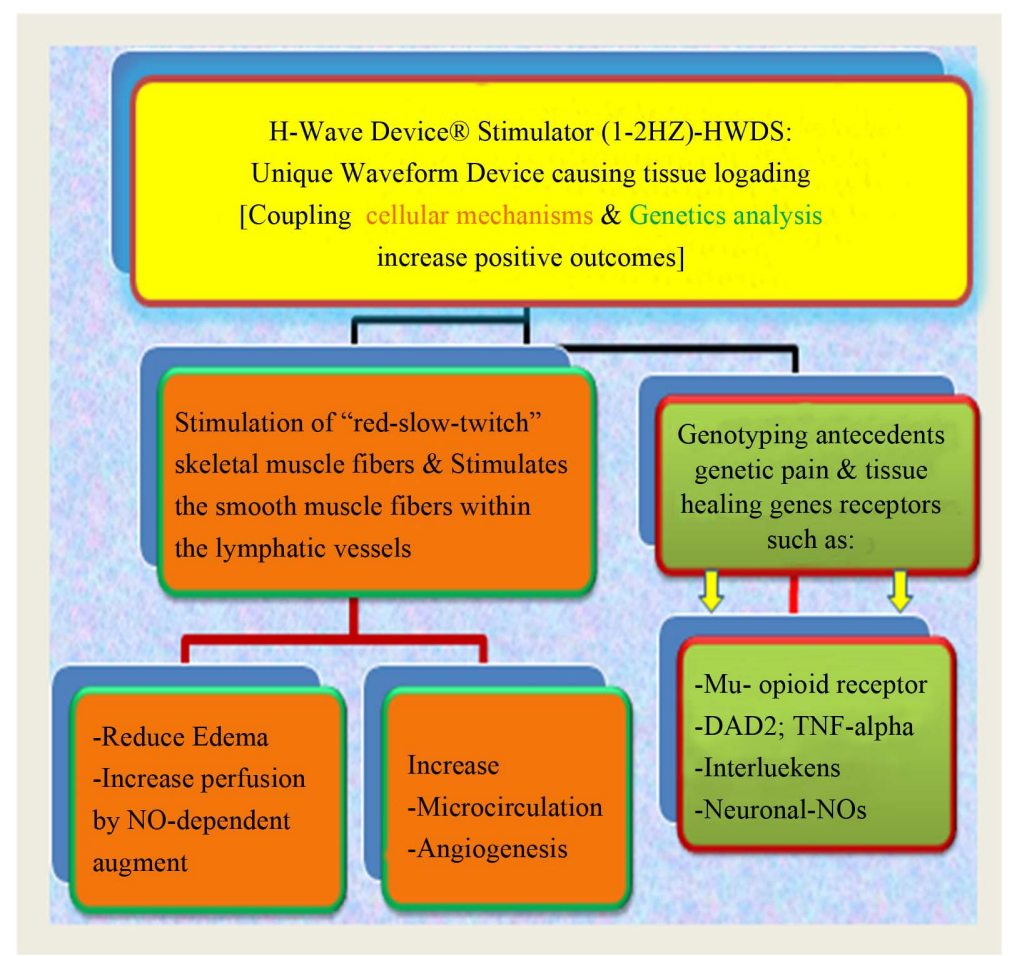

Figure 1. Illustrates loading of H-Wave coupling cellular mechanisms and genetic analysis.

Medicine (evidence in a few rats) suggest that HWDS induces protein clearance. Although, this may occur by the purely mechanical event of inducing contraction of lymphatic smooth muscle, it would be of interest to assess the role of HWDS in protein clearance and to determine fibronectin activity in injured tissue pre and post HWDS.

\subsection{Clinical Implications}

An examination of the literature has revealed that early controlled activity promotes healing of bone, tendon, ligament, and skeletal muscle. While there is more intensive research left to be done regarding the optimal application of controlled tissue loading and the effects of loading under these conditions, we cautiously suggest that the incorporation of HWDS certainly when the injured loci is stabilized should confer a positive healing outcome. There are a number of important clinical points that must be considered. In particular, loading of injured bone, tendon, ligament, and skeletal muscle should be minimized during the period of acute inflammation response that follows tissue injury. Variables include; the type of injury and type of tissue repair required the time from tissue inflammatory response and formation of the initial repair. Buckwalter and Grodzinsky [29] provide a schematic discussion of when to apply loading for different types of injury and tissue repair. Accordingly, they suggest that in a clinical setting, loading of healing tis- sues may be done with various combinations of both active and passive motion with or without any resistance, or even by isometric muscle contraction.

An important clinical aspect that should be considered herein, is that animal research has shown that repetitive HWDS induces significant angiogenesis compared with single or intermittent HWDS $[11,13]$. This finding supports the concept that tissue healing may be induced by adding tissue loading. As mentioned earlier, muscular contraction or shear-wall stress is the best-known factor for the intrinsic production of angiogenesis. Interestingly, by stimulating slow-twitch myofibrils, with associated mitochondria activity, a larger and denser network of new blood vessel formation or angiogenesis will occur. As stated earlier we would like to emphasize that although other electrotherapeutic devices can cause tissue loading due to muscle contraction using fast-twitch muscle fibers (e.g., TENS, EMS, NMES , High-volt galvanic, interferential [IF]), H-Wave ${ }^{\circledR}$ therapy utilizes slow twitch muscle fibers in a non-fatiguing contraction and because of this property has been shown to induce fluid shifts as determined by MRI studies $[10,20]$ and the resultant enhanced microcirculation is dependent on $\mathrm{NO}$ mechanisms(s) [13].

Finally, these microvascular and hemodynamic findings coupled with the state of the art concept of the applicability of tissue loading provide an understanding of the mechanisms linked to increased perfusion, and tissue 
repair and remodeling. We suggest that following additional confirmatory research in both animals and humans evaluating HWDS effects on stress vs. strain (measurement of tension), measurements of loading (dynes) and stiffness, we have potentially achieved scientific advancement; that is an alternative to addicting pharmacological analgesics and toxic anti-inflammatory agents that could also induce loading with a concomitant increase in tissue healing. To reiterate, a meta-analysis [20] found a moderate to strong effect of the HWDS in providing pain relief, reducing the requirement for pain medication(s), and increasing functionality. The most robust effect was observed for improved functionality, suggesting that the $\mathrm{H}$-Wave ${ }^{\circledR}$ device and program may facilitate a quicker return to work.

Most recently a double-blinded study involving $\mathrm{H}$-wave pad-placement immediately following rotator cuff surgery used low frequency (tension control) gradually increases in intensity over the course of the experiment. This experiment yielded a very significant positive outcome especially as related to range of motion (ROM) and agrees with the potential for early muscle loading in wound healing [29]. HWDS compared to placebo induced a significant increase in ROM in positive management of rotator cuff reconstruction, supporting other previous research on HWDS and improvement in function. Interpretation of this preliminary investigation while suggestive of significant increases in ROM of Post-Operative Rotator Cuff Reconstruction, warrants further confirmation in a larger double-blinded sham controlled randomized study [21].

Interestingly, the ability to control loading tension by HWDS may provide an earlier intervention that will assist in tissue healing without interrupting the natural healing process as discussed by Buckwalter and Grodzinsky [29]. They described when to initiate muscle loading as follows:

"In some minor injuries and following certain surgical procedures, there is minimal acute inflammation, and the tissues are stable; in that situation, motion and loading can be initiated almost immediately. When there is minimal tissue loss or necrosis, little disruption of the blood supply, and close approximation of the surfaces of the injured tissues, the initial repair tissue forms within 3 to 10 days. Examples of these types of injuries include closed impacted or minimally displaced metaphyseal fractures, repaired flexor tendon lacerations, medial collateral ligament tears, and skeletal muscle strains. Motion and loading of these injured tissues can be started as soon as the acute inflammation and accompanying pain have subsided. In injuries with segmental tissue loss, compromised blood supply, or large gaps between tissue surfaces, formation of the initial repair tissue requires more time. Loading before stable repair tissue has formed may adversely affect the result. In the clinical setting, loading of healing tissues may be done with various combinations of active and passive motion, with or without resistance, or by isometric muscle contraction" [29].

There are known genetic anteceedents to addiction liability and as such we turn our attention to the important role of neurotransmitters especially dopamine and pain sensitivity.

\subsection{Pharmacological of Pain Control}

Opioids like heroin and morphine and psychostimulant drugs like amphetamine are pharmacologically effective in treatment of chronic pain. Interestingly, amphetamine and related drugs that can potentiate opioid analgesia and counter cognitive disturbances and opioid-related sedation are sometimes administered as an adjuvant analgesic to relieve cancer pain. Studies in rats have shown that psychostimulants potentiate the analgesic effect of morphine in an animal model of persistent pain support these clinical findings [78]. Evidence that sites rostral to the brainstem play a crucial role in the effects of opioid analgesics and psychostimulant drugs is increasing.

Opioids acting at sites in the brainstem and spinal sites can inhibit pain. They modulate the activity of the descending pathways of the brain stem that project onto the spinal cord. The periacqueductal gray of the brain stem is a primary site of action where opioid receptors are activated at the nucleus raphe magnus, by direct projections onto serotonin-containing cells. In turn, these cells activate neurons that project to the dorsal horns of the spinal cord, via the dorsolateral funiculus, where they inhibit cells that transmit information about noxious (painful) stimulation to supraspinal sites from the periphery. The role of the descending brainstem pain-suppression system plays, is larger, in the suppression of brief, rapidly rising, transient, and well-localized phasic pain, than it is in the suppression of injury-produced persistent inescapable tonic pain. However, several lines of evidence suggest that the inhibition of tonic pain requires the activation of dopaminergic neural systems in addition to those required to inhibit phasic pain $[79,80]$.

\subsection{Mesolimbic Dopamine in the Suppression of Tonic Pain}

There is little information to date concerning the identity of the endogenous pain systems that serve to inhibit tonic pain. The suppression of tonic pain involves systems in addition to those known to suppress phasic pain, and that these systems appear to involve forebrain sites, rostral to the brainstem. A clue to this problem is that both opioids and psychostimulants reduce tonic pain and increase transmission in mesocorticolimbic dopamine 
neurons known to be activated by natural rewards such as food and sex. These neurons arise from dopamine cell bodies that lie in the ventral tegmental area (VTA) and project to various forebrain sites such as the nucleus accumbens (Nacc), amygdala, and prefrontal cortex. Opioids cause the release of dopamine from these neurons through their indirect activation (see reward cascade Figure 2), whereas psychostimulant drugs such as amphetamine and cocaine increase dopamine extracellularly by decreasing reuptake and/or inducing release. Moreover, opioids and psychostimulants have both rewarding effects and analgesic effects in the clinical setting, suggesting that reward and analgesia might share common neural substrates [81]. It was found that dopamine-depleting 6-hydroxydopamine lesions of the ventral midbrain, which contains the cell bodies of the neurons that give rise to ascending forebrain projections, block the analgesic effects of systemic morphine and amphetamine in the formalin, but not the tail-flick test. Their findings provided the first evidence that mesolimbic dopamine neurons play a role in the suppression of tonic, but not phasic pain. In recent studies, Taylor et al. [82], found that while the D1-selective agonist SKF 38393 was without effect at a dose of $0.5 \mathrm{nmol} / \mathrm{side}$, the D2-selective agonist quinpirole dose dependency $(0.05$ - 5 onmol/side, bilateral) inhibited the persistent phase of formalin-induced nociception. This was blocked by pre-administration of a selective D2-dopaminergic antagonist raclopride. These results indicate dopamine agonists that activate D2 receptors in the Nacc, inhibit inflammatory pain.

In this cascade, stimulation of the serotonergic system in the hypothalamus leads to the stimulation of delta/mu receptors by serotonin to cause a release of enkephalins. Activation of the enkephalinergic system induces an inhibition of GABA transmission at the substantia nigra by enkephalin stimulation of mu receptors at GABA neurons. Both the endocannabinoid and glutamate receptors influence GABAergic activity. This inhibitory effect allows for the fine tuning of GABA activity. This provides the normal release of dopamine at the projected area of the NAc, a major reward site of the brain (Blum et al. 2013 with permission [83]).

\subsection{Dopamine D2 Receptors and Chronic Pain}

Changes in synaptic neurotransmission plasticity are thought to have a role in chronic pain. Animal studies suggest that dopaminergic systems in the striatum and cortex of the brain participate in pain modulation and transmission. In animal models for persistent pain, a role for dopamine D2 receptors has been reported in the mediation of pain inhibition by dopamine [84]. Hagelberg et al. [85] showed using positron emission tomography (PET) that hypodopaminergic function is associated with pain due to burning mouth syndrome. This effect involves mu receptor interaction [86]. Furthermore, increased D2 receptor availability possibly due to decreased $^{[18 \mathrm{~F}]}$ FDOPA uptake, have been demonstrated in the putamen in, burning mouth syndrome. Furthermore, the increase in left putamen D2 receptor availability and the decrease in D1/D2 ratio imply that altered striatal dopamineric system as evaluated by PET may also be involved in chronic orofacial pain conditions [87]. Essentially, we hypothesize here that low neurological dopaminergic function may herold a predisposition to low pain tolerance. With support from current research for this concept, carriers of the D2 Taq A1 allele as seen in Reward Deficiency Syndrome (RDS) behaviors may need to enhance their dopamine release with a neuro nutrient D2 agonist to boost their pain tolerance [88].

\subsection{Stress and Pain}

The effects of excessive stress in modern life lead to chronic states of fatigue-related depression. According to the American Academy of Family Physicians, about 2/3 of all office visits are related to stress and depression. Numerous examples in the literature support the contention that an individual with chronic pain, is indeed in a stressful condition which increases neuronal firing. Furthermore, numerous studies have shown that if an individual has the DRD2A1 variant of the DRD2 gene, the dopamine D2 receptors reduction is associated with an inability to cope with stress [89-91]. D2 receptor messager RNA (mRNA) can also be reduced by stress, in the substania nigra the lateral part of the VTA, the basal ganglia, and especially in the NAc [92].

The concept that dopamine systems in the forebrain are involved in mediating the behavioral effects of mild chronic stress is supported in this work. Further, the view that in subjects with pain and resultant chronic mild to moderate stress, reduced D2 receptor site density, reduced mRNA message and enhanced catecholaminergic neuron firing frequency would be quite receptive to 1-tyrosine, a dopamine precursor is also supported here. Moreover, it is known that neuronal dopamine depletion can induce an independent inhibitory state endproduct for tyrosine-hydroxylase, which will also respond to 1-tyrosine supplementationn. In this regard, in order to provide an up-regulation in D2 receptors, we propose a natural and personalized solution designed to facilitate a gradual and constant release of dopamine, the effect of enhanced opioidergic activity due to d-phenylalanine (a known enkephalinase inhibitor) on substania nigra GABA neurons. The main point here is that pharmacological manipulation of up-regulation of dopaminergic pathways will ultimately lead to reduction of stress since it well known that the dopamine molecule is considered the endogenous anti-stress substance. 


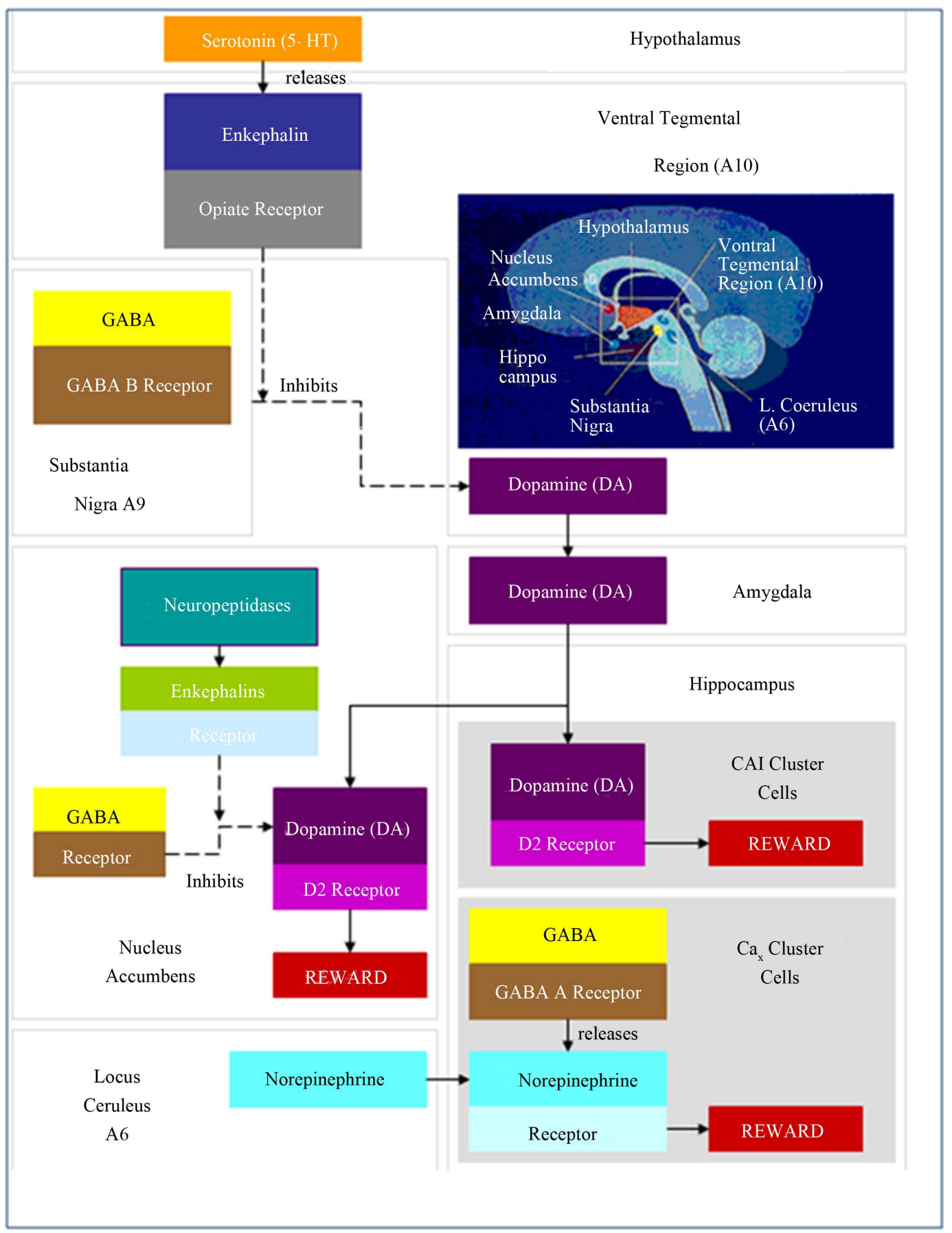

Figure 2. Brain reward cascade.

\subsection{The Pathophysiology of Chronic Widespread Pain as Implied by Stress and Dopamine}

The relationship between endorphins, stress, and hypothalmic-pituitary-adrenal (HPA) axis is well researched [93]. Certainly stress plays a critical role in both addiction and relapse. It is known that certain environmental and genetic elements play a significant role in dysregulation of brain reward pathways and drug de- pendency. In fact, polymorphisms of the dopamine D2 receptor have been associated with mechanisms for coping with stress and posttraumatic stress disorder [94]. Interestingly, stress can both exacerbate the pain or even induce a painful condition. Dopamine transmission in mesocorticolimbic dopamine neurons is activated by exposure to stress [95]. This effect in the VTA appears to involve opioid mechanisms. Specifically, intra-VTA infusions of naltrexone, the opioid receptor antagonist, 
prevent the stress-induced activation of dopamine metabolism in the prefrontal cortex and NAc and block stress-induced analgesia in the formalin test $[79,80]$, while stress exposure, causes met-enkephalin release into the VTA [96]. This observation when combined with findings that indicate that tonic pain can be inhibited by exposure to stress and analgesia in the formalin test, is induced by intra-VTA morphine, suggest that a mechanism that underlies the stress-induced inhibition of tonic pain might be the endogenous release of opioids in the VTA. In addition, a similar role for the release of the tachykinin neuropeptide, substance P (SP), in the stress-induced suppression of tonic pain in the VTA has been proposed. Indeed, midbrain dopamine neurons activated by SP did inhibit tonic pain in the formalin test [79]. The current data suggest a release of SP in the VTA caused by exposure to stress induces analgesia which activates mesocorticolimbic dopamine neurons. Finally, the ability to increase dopamine release into the NAcc is shared by opioids, amphetamine and SP. Moreover, dopamine metabolism and extracellular levels of dopamine in the NAc are augmented by opioids administered systemically or into the VTA.

With that background, it follows that this hypothesis; that dopamine D2 activation can attenuate tonic pain, we embrace the concept of supportive research in the area of developing a natural method that can induce the preferential release of dopamine in mesocorticolimbic pathways. Thus support of an attenuation of stress has been found with a variant of a complex with dopaminergic activation properties shown in one double-blind placebo controlled study [97]. We further hypothesize herein that unless there is a way of increasing endogenous opioids, which in turn inhibit GABA causing dopamine release in the NAc, simple neurotransmitter precursors will not be as effective in reducing tonic pain.

\subsection{Clinical Perspectives}

Together with the current findings that HWDS or other similar electrotherapeutic devices bring about pain relief, increase tissue perfusion, blood flow, induce NO-dependent tissue microcirculation and angiogenesis (during repetitive stimulation), tissue loading should be included in a clinical approach to facilitate recovery from tissue injury.

Being cognizant that there are a variety of methods, including the use of cytokines, cell transplants, and gene therapy, to restore, repair and remodel injured tissue, the addition of a modality purported to cause loading in a non-fatiguing and non-tetanizing way focused at overcomeing the pain and loss of function associated with tissue injury should be considered.

Our review of this core of associated research provides reasonable rational to propose that when used appropriately, HWDS could improve tissue healing.

Recent advances in the field of muscle recovery and endurance have indicated that a number of interesting MOA are linked to the healing process. The newly accepted view that lactate is not just a by-product of extreme exercise but an important cellular energy fuel has relevance to the healing process involved in tissue injury $[98,99]$. Additionally, generation of NO appears to be an important player, possibly acting as a unifying molecular switch to trigger the whole cascade of the mitochondrial biogenesis process [100]. Chronic, small increases in NO levels stimulate mitochondrial biogenesis in muscle cells [101]. Moreover, it could be inferred that the generation by HWDS of increased muscle oxygenation (needed for energy production) may induce an increase in new blood vessel formation by either shear force or putatively increasing angiogenesis factors at the site of chronic muscle stimulation [102]. For example, specific adaptive responses to endurance or resistance training-like electrical muscle stimulation induce the endurance protein PGC-1G alpha. Interestingly, the level of PGC-1G alpha effects human physical performance is dependent upon an association with the PPARG gene polymorphism [103].

Understanding these newer concepts especially as they are related to loading of injured tissue could impact clinical practice. The importance of proper loading to achieve normal healing is underscored when we consider the differences observed between immobilization compared to mobilization especially with reference to scar (collagen) tissue formation in, for example, ligaments. Lo et al. [99] characterized the cellular organization of the anterior cruciate ligament (ACL) and the ovine medial collateral ligament (MCL). They compared the organization of healthy ligaments with that found in healing ligaments. Over time they found that both the ACL and MCL scars displayed discontinuities in their cellular rows. However, the scars of the MCL contained discontinuities filled with cellular projections and gap junctions, while, discontinuities in ACL scars were devoid of cells and gap junctions. The authors [104] correctly suggested that the differences between normal and scar cytoarchitecture and these discontinuities may provide the structural basis for the altered biomechanics of healing ligaments and/or represent features of an inadequate healing response. Moreover, others [105] have evaluated the changes which occurred in the epiligament, an enveloping tissue of the ligament, during the ligament healing. The results revealed that on the eighth, thirteenth and sixteenth day of post-injury, the epiligament tissue is not completely regenerated. Understanding that the tissue is not fully restored led the authors to discuss new strategies for healing including appropriate loading techniques. 
The use of the H-Wave ${ }^{\circledR}$ device and program is actually shown by experimentation to cause significant tissue loading in the early stages of tissue repair.

To summarize, the process of healing tissues involves many factors predominantly: 1) loading of bone, fibrous tissue and muscle; 2) NO dependent increase in blood flow; 3) increase in protein clearance at injured loci; 4) increased formation of new blood vessels or angiogenesis; 5) increased absorption of cellular lactate and 6) increased mitochondrial biogenesis (see Figure 3).

H-wave ${ }^{\circledR}$ HWDS showing proposed cellular response mechanisms derived from evidence-based medical published articles [9-26].

\section{CONCLUSION}

We conclude that, in addition to providing a safe, non-addicting, alternative to pain medication, HWDS may promote tissue healing. Support for this hypothesis, albeit the need for more intensive research, is derived from both animal and human studies delineated in this article [see Table 1]. Further genotyping for certain genetic antecedents for pain and tissue healing (e.g. muopioid receptor, dopamine D2 receptor, TNF-alpha, interleukins and eNOs) may significantly increase positive outcomes in the utilization of the HWDS. While, as yet, we do not have genotyping information about the reason why we are actively pursuing this novel approach.

Thus, the use of electrotherapy should enhance tissue responses that can restore structure and function after injury. Based on evidence provided by these studies, the complex interrelated series of events that commences with the release of inflammatory mediators and ends when remodeling of the repair tissue are augmented by electrotherapy. They include: cellular (NO production); humoral (release of VGEF); vascular events (increased blood flow followed by angiogenesis); increased cellular absorption of lactate; enhanced mitochondrial biogenesis, and potential induction of PPAR gamma gene with concomitant production of protein PGC-1G alpha and are a continuous sequence that reaches a homeostatic state leading to the remodeling stage.

Utilization of electrotherapy may be a wise decision by clinicians as an analgesic alternative to powerful legal opioids. With increasing knowledge and understanding of the benefit of genetic testing in terms of medication monitoring through, for example, genotyping for the metabolic P450 system and reward genes as proposed in the GARS test, analgesic therapy could be personalized

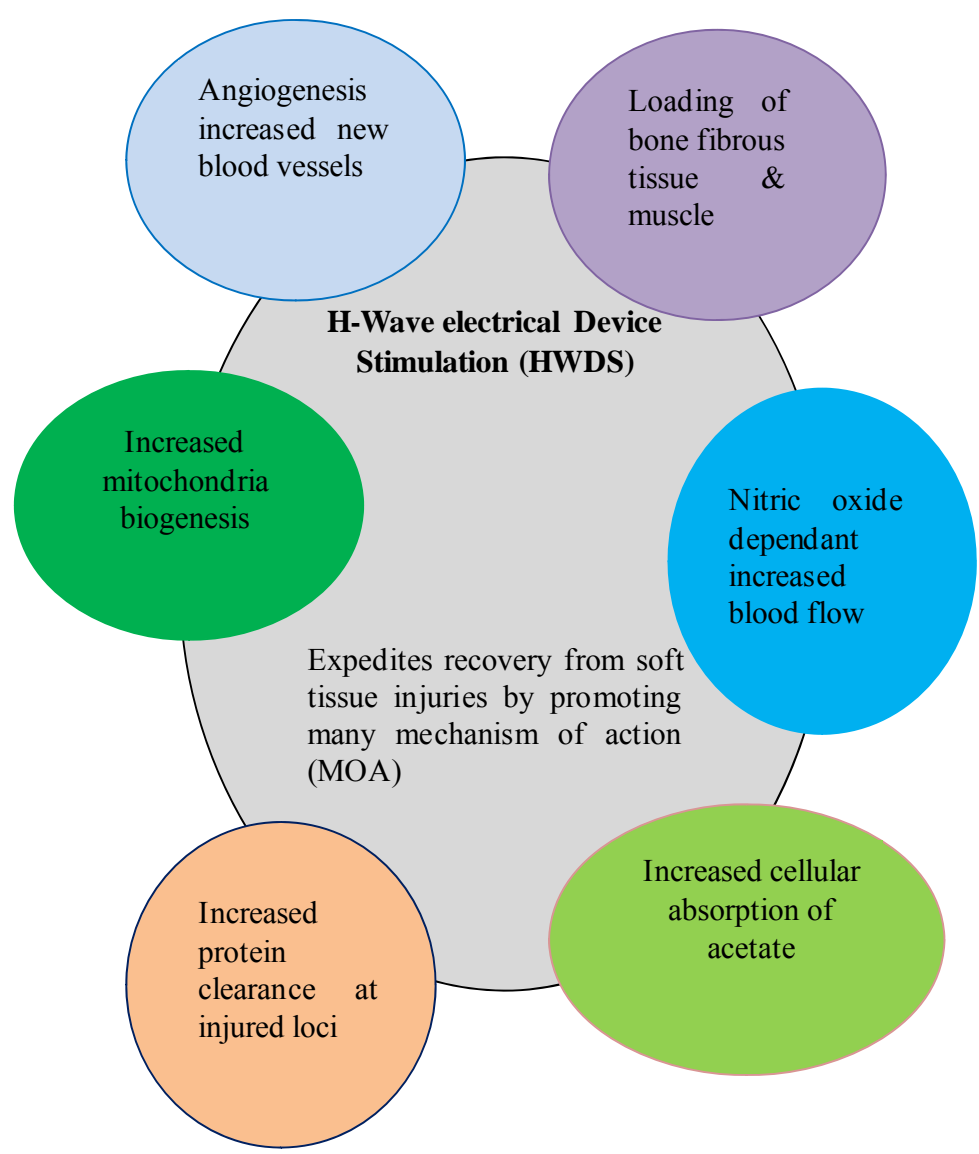

Figure 3. HWDS cellular response mechanisms. 
Table 1. Summary of H-Wave ${ }^{\circledR}$ pre-clinical and clinical trials.

\begin{tabular}{|c|c|c|c|c|}
\hline Author & Study Type & $\mathbf{N}$ & Main outcome & Linked MOA for healing \\
\hline Kumar et al. [9] & $\begin{array}{l}\text { RSC-chronic painful } \\
\text { peripheral neuropathy }\end{array}$ & 31 & $\begin{array}{c}\text { In the sham group, } 38 \% \text { had reduction of pain compared } \\
\text { with } 83 \% \text { in the HWDS group }(P<0.05)\end{array}$ & $\begin{array}{l}\text { The study proposed increased } \\
\text { microcirculation and fluid shifts }\end{array}$ \\
\hline $\begin{array}{l}\text { Kumar et al. } \\
\qquad[14,15]\end{array}$ & $\begin{array}{l}\text { RDBSC-chronic painful } \\
\text { peripheral neuropathy with } \\
\text { combined amitriptyline }\end{array}$ & 26 & $\begin{array}{l}\text { In the amitriptyline group, } 60 \% \text { of the } \\
\text { patients had reduction of pain. } \\
\text { When combined with HWDS; } 85 \% \text { had } \\
\text { significant pain reduction }(P<0.01) \text {. }\end{array}$ & $\begin{array}{l}\text { The study proposed that } \\
\text { HWDS enhanced the effect of } \\
\text { amitriptyline by inducing wound } \\
\text { healing in diabetic patients. }\end{array}$ \\
\hline Blum et al. [17] & $\begin{array}{l}\text { COS in patients with } \\
\text { chronic pain and } \\
\text { inflammation from injuries } \\
\text { of the lower, upper } \\
\text { extremities, and back }\end{array}$ & 1797 & $\begin{array}{l}\text { More than } 60 \% \text { of patients with pain experienced } \\
\text { pain relief above } 25 \% \text {; over } 50 \% \text { of patients improved } \\
\text { function; } 40 \% \text { of patients reduced or eliminated pain } \\
\text { medications; the proportion of patients who reported } \\
\text { improvement was significantly higher than the } \\
\text { expected response to placebo therapy }(P<0.01) \text {. }\end{array}$ & $\begin{array}{l}\text { The study proposed } \\
\text { anti-inflammatory effects, } \\
\text { increased microcirculation, } \\
\text { fluid shifts and wound healing. }\end{array}$ \\
\hline Blum et al. [18] & $\begin{array}{l}\text { COS in patients with chronic } \\
\text { pain and inflammation from } \\
\text { injuries of the lower, upper } \\
\text { extremities, and spine }\end{array}$ & 6774 & $\begin{array}{l}65 \% \text { of subjects reported a reduced or eliminated need } \\
\text { for pain medication; } 79 \% \text { reported improved function } \\
\text { and } 78 \% \text { reported } 25 \% \text { or greater reduction of pain. }\end{array}$ & $\begin{array}{l}\text { The study proposed } \\
\text { anti-inflammatory effects, } \\
\text { increased microcirculation, } \\
\text { fluid shifts and wound healing. }\end{array}$ \\
\hline Tsang et al. [25] & $\begin{array}{l}\text { RCRS-rats received } \\
\text { HWDS for } 21 \text { days } \\
\text { following ligation of } \\
\text { left sciatic nerve } \\
\text { compared with no HWSD }\end{array}$ & 20 & $\begin{array}{l}\text { Animals in the HWDS group showed reduced } \\
\text { thermal hypersensitivity with longer withdrawal } \\
\text { latencies after daily application of electrical } \\
\text { stimulation to the ligated nerve. This result may } \\
\text { have potential in sport-related spine injuries. }\end{array}$ & $\begin{array}{l}\text { The study showed a reduced } \\
\text { thermal hypersensitivity } \\
\text { important for tissue } \\
\text { injury healing. }\end{array}$ \\
\hline Flatt [26] & $\begin{array}{l}\text { CSP-patient with double } \\
\text { crush syndrome }\end{array}$ & 1 & $\begin{array}{l}\text { One-year utilization of HWDS resulted in } \\
\text { complete resolution of the right anterior leg numbness } \\
\text { and reduced occurrence of lower back pain. }\end{array}$ & $\begin{array}{l}\text { The study showed a reduction } \\
\text { of numbness due to double } \\
\text { crushed syndrome which } \\
\text { affected back pain. }\end{array}$ \\
\hline Smith et al. [12] & $\begin{array}{l}\text { RCSRS-rats were studied } \\
\text { for microcirculatory and } \\
\text { hemodynamic effects of } \\
\text { HWDS using stimulation } \\
\text { to the cremaster muscle } \\
\text { and hind limbs }\end{array}$ & 67 & $\begin{array}{l}\text { HWDS compared with sham induced a } 26 \%-62 \% \\
\text { significant increase in blood flow. This response was } \\
\text { completely blocked with L-NAME showing that the } \\
\text { response was nitric oxide-dependent. Compared with } \\
\text { sham chronic HWSD to the hind limbs for } 21 \text { days, } \\
\text { resulted in a } 247 \% \text { increase in blood flow. In the } \\
\text { untreated leg, acute HWDS caused only a } 200 \% \\
\text { increase. This } 25 \% \text { difference was due to } \\
\text { angiogenesis in only the chronically HWDS-treated leg. }\end{array}$ & $\begin{array}{l}\text { The study showed } \\
\text { enhanced microcirculation } \\
\text { which was NO-dependent. }\end{array}$ \\
\hline Smith et al. [13] & $\begin{array}{l}\text { RCSRS-rats were studied } \\
\text { for microcirculatory and } \\
\text { hemodynamic effects of } \\
\text { HWDS using stimulation } \\
\text { of muscle to hind limbs }\end{array}$ & 10 & $\begin{array}{l}\text { Animals were HWDS-conditioned ("Conditioned") or } \\
\text { sham-stimulated ("Sham") ( } \mathrm{n}=5 \text { /group) daily for } \\
\text { three weeks. The contralateral limb in both groups } \\
\text { served as the control. Each animal was injected with } \\
\text { bromodeoxyuridine (BrDU). After } 3 \text { weeks, rats were } \\
\text { anesthetized and iliac artery blood flow was measured } \\
\text { bilaterally before, during, and after acute HWDS. } \\
\text { HWDS of the Conditioned limbs elicited a } 247 \\
\text { percent increase in blood flow above resting } \\
\text { conditions compared to a } 200 \text { percent increase } \\
\text { in control legs. Sham animals did not demonstrate } \\
\text { between-leg differences in flow. }\end{array}$ & $\begin{array}{l}\text { Hindlimb musculature staining } \\
\text { for BrDU revealed angiogenesis } \\
\text { in Conditioned } v \text {. Sham groups. } \\
\text { Flow changes accompanying } \\
\text { HWDS corroborated earlier } \\
\text { microvascular findings } \\
\text { demonstrating a significant } \\
\text { striated muscle arteriolar } \\
\text { dilation with HWDS }\end{array}$ \\
\hline Blum et al. [21] & $\begin{array}{l}\text { RDBSC-rotator cuff } \\
\text { reconstruction in } \\
\text { patients using HWDS } \\
\text { postoperative }\end{array}$ & 22 & $\begin{array}{l}\text { Patients who received HWDS compared with placebo } \\
\text { demonstrated, on average, significantly improved range } \\
\text { of motion. Results confirm a significant difference for } \\
\text { external rotation at } 45 \text { and } 90 \text { days postoperatively; } \\
\text { active range at } 45 \text { days postoperatively }(P=0.0079) \text {, } \\
\text { active at } 90 \text { days postoperatively }(P=0.0079) \text {.Internal } \\
\text { rotation also demonstrated significant improvement } \\
\text { compared to placebo at } 45 \text { and } 90 \text { days postoperatively; } \\
\text { active range at } 45 \text { days postoperatively }(P=0.0072) \text {, } \\
\text { and active range at } 90 \text { days postoperatively }(P= \\
0.0062) \text {. There was no significant difference } \\
\text { between the } 2 \text { groups for strength testing. }\end{array}$ & $\begin{array}{l}\text { The study showed improved } \\
\text { range of motion and } \\
\text { increased strength } \\
\text { following HWDS. }\end{array}$ \\
\hline
\end{tabular}




\begin{tabular}{|c|c|c|c|c|}
\hline Blum et al. [22] & $\begin{array}{c}\text { CSP in patients } \\
\text { with chronic venous } \\
\text { stasis ulcers }\end{array}$ & 3 & $\begin{array}{l}\text { One patient with chronic venous stasis for } 6 \text { years, } \\
\text { was dispensed a home H-Wave }{ }^{\circledR} \text { unit on } 11-09-98 \text {. } \\
\text { Following treatment, the ulcer completely healed with } \\
\text { the H-Wave }{ }^{\circledR} \text { device and program on } 2-17-99 \text {. A second } \\
\text { patient with chronic stasis ulcer for three } \\
\text { weeks received once a week H-Wave }{ }^{\circledR} \text { therapy with } \\
\text { traditional compressive therapy on } 4-14-98 \text {. By 5-12-98 } \\
\text { (1 month), complete ulcer closure occurred. Finally, a } \\
\text { third patient with a chronic venous stasis ulcer for } 2 \\
\text { years was dispensed a home H-Wave }{ }^{\circledR} \text { unit and } \\
\text { weekly wound care; following this treatment, no } \\
\text { other treatment was applied, and a completely } \\
\text { healed ulcer resulted on 5-11-99 (9 months). }\end{array}$ & $\begin{array}{l}\text { The study showed } \\
\text { enhanced wound healing. }\end{array}$ \\
\hline Blum et al. [10] & $\begin{array}{l}\text { OLCL-Magnetic } \\
\text { Resonance Imaging } \\
\text { (MRI)experiment }\end{array}$ & 3 & $\begin{array}{l}\text { MRI revealed important muscle } \\
\text { fluid shifts following HWDS. }\end{array}$ & $\begin{array}{l}\text { The study showed fluid } \\
\text { shifts following HWDS } \\
\text { which could have important } \\
\text { ramifications in reducing } \\
\text { injury induced edema and } \\
\text { enhanced circulation. }\end{array}$ \\
\hline
\end{tabular}

Abbreviations: MOA, mechanism of action; RSC, randomized single-blind sham-controlled; COS, chronic observational study via post-hoc questionnaire; CSP, case study perspective; RCRS, randomized controlled rat study; RCSRS, randomized controlled sham rat study; RDBSC, randomized double-blind sham-controlled; HWDS, H-Wave ${ }^{\circledR}$ device stimulation; L-NAME, L-nitro-arginine methyl ester, SPPC Each subject served as their own control pre to post measurement, OLCT, open label clinical trial.

with reducing the risk of addiction liability [83]. Finally, these modalities may have a beneficial therapeutic impact on the dilemma of endemic of the opioid prescription in the United States and abroad [5-8,106-109].

\section{ACKNOWLEDGEMENTS}

The authors would like to thank the staff at Path Research Foundation NY, New York, New York, as well as financial support. The authors acknowledge the financial support of Electronic Waveform lab of Huntington Beach, California. Marlene Oscar-Berman, $\mathrm{PhD}$ is the recipient of grants from the National Institutes of Health, NIAAA (RO1-AA07112 and K05-AA00219) and the Medical Research Service of the US Department of Veterans Affairs. Kenneth Blum, PhD and Eric Braverman, MD are recipients of a grant from Life Extension Foundation, Ft. Lauderdale, Florida, USA.

\section{REFERENCES}

[1] CDC grand rounds: Prescription drug overdose-A US epidemic. (2012) 10-13. www.cdc.gov/mmwr/preview/mmwrhtml $/ \mathrm{mm} 6101 \mathrm{a} 3 . \mathrm{htm}$

[2] Dunn, K.M., Saunders, K.W., Rutter, C.M., Banta-Green, C.J., Merrill, J.O., Sullivan, M.D., Weisner, C.M. Michael J. Silverberg, M.J., Campbell, C.I., Psaty, B.M. and Von Korff, M. (2010) Opioid prescriptions for chronic pain and overdose. Annals of Internal Medicine, 152, 85-92. http://dx.doi.org/10.7326/0003-4819-152-2-201001190-0 $\underline{0006}$

[3] Boudreau, D., Von Korff, M., Rutter, C.M., Saunders, K., G. Thomas Ray, T., Sullivan, M.D., Campbell, C., Merrill, J.O., Silverberg, M.J., Banta-Green, C. and Weisner, C. (2009) Trends in long-term opioid therapy for chronic non-cancer pain. Pharmacoepidemiology and Drug Safety,

\section{8, 1166-1175. http://dx.doi.org/10.1002/pds.1833}

[4] Substance Abuse and Mental Health Services Administration (2010) Results from the 2009 national survey on drug use and health: Volume 1: Summary of national findings. Substance Abuse and Mental Health Services Administration, Rockville.

[5] Edlund, M.J., Martin, B.C., Fan, M.Y., Braden, J.B., Devries, A. and Sullivan, M.D. (2010) An analysis of heavy utilizers of opioids for chronic noncancer pain in the TROUP Study. Journal of Pain and Symptom Management, 40, 279-289.

http://dx.doi.org/10.1016/j.jpainsymman.2010.01.012

[6] Katz, N., Panas, L., Kim, M., Audet, A.D., Bilansky, A., Eadie, J., Kreiner, P., Paillard, F.C., Thomas, C. and Carrow, G. (2010) Usefulness of prescription monitoring programs for surveillance-Analysis of schedule II opioid prescription data in Massachusetts, 1996-2006. Pharmacoepidemiology and Drug Safety, 19, 115-123. http://dx.doi.org/10.1002/pds.1878

[7] Bohnert, A.S., Valenstein, M., Bair, M.J., Ganoczy, D., McCarthy, J. F., Ilegen, M. A. and Blow, F.C. (2011) Association between opioid prescribing patterns and opioid overdose-related deaths. JAMA, 305, 1315-1321. http://dx.doi.org/10.1001/jama.2011.370

[8] Hall, A.J., Logan, J.E., Toblin, R.L., Kaplan, J.A., Kraner, J.C., Bixler, D., Crosby, A.E. and Paulozzi, L.J. (2008) Patterns of abuse among unintentional pharmaceutical overdose fatalities. JAMA, 300, 2613-2620. http://dx.doi.org/10.1001/jama.2008.802

[9] Kumar, K., Taylor, R.S., Jacques, L., Eldabe, S., Meglio, M., Molet, J., Thomson, S., O’Callaghan, J., Eisenberg, E., Milbouw, G., Buchser, E., Fortini, G., Richardson, J. and North, R.B. (2007) Spinal cord stimulation versus conventional medical management for neuropathic pain: A multicentre randomized trial in patients with failed 
back surgery syndrome. Pain, 132, 179-188. http://dx.doi.org/10.1016/i.pain.2007.07.028

[10] Blum, K., Chen, T.J. and Ross, B.D. (2005) Innate properties of $\mathrm{H}$-wave device, a small fiber stimulator provides the basis for a paradigm shift of electro-therapeutic treatment of pain with increased functional restoration associated with human neuropathies by affecting tissue circulation: A hypothesis. Medical Hypotheses, 64, 10661067. http://dx.doi.org/10.1016/j.mehy.2004.11.033

[11] Blum, K., Ho, C.K., Chen, L.C., Fulton, M., Fulton, B., Westcott, W., Reinl, G., Braverman, E.R., Dinubile, N. and Chen, T.J.H. (2008) The H-wave device induces $\mathrm{NO}-$ Dependent augmented microcirculation and angiogenesis, providing both analgesia and tissue healing in sports injuries. The Physician Sports Medicine, 36, 103114. http://dx.doi.org/10.3810/psm.2008.12.18

[12] Smith, T.L., Blum, K., Callahan, M.F., Di Nubile, N.A., Chen, T.J. and Waite, R.L. (2009) H-wave induces arteriolar vasodilation in rat striated muscle via Nitric Oxide-mediated mechanisms. Journal of Orthopaedic Research, 27, 1248-1251. http://dx.doi.org/10.1002/jor.20851

[13] Smith, T.L., Blum, K., Waite, R.L., Heaney, W.J. and Callahan, M. (2007) The microvascular and hemodynamic mechanisms for the therapeutic actions of H-wave muscle stimulation. The 6th Combined Meeting of the Orthopaedic Research Societies, 21 October 2007, Honolulu.

[14] Kumar, D. and Marshall, H.J. (1997) Diabetic peripheral neuropathy: Amelioration of pain with transcutaneous electrostimulation. Diabetes Care, 20, 1702-1705. http://dx.doi.org/10.2337/diacare.20.11.1702

[15] Kumar, D., Alvaro, M.S. and Julka, I.S. (1998) Marshall HJ: Diabetic peripheral neuropathy: Effectiveness of electrotherapy and amitriptyline for symptomatic relief. Diabetes Care, 21, 1322-1325. http://dx.doi.org/10.2337/diacare.21.8.1322

[16] Julka, I.S., Alvaro, M. and Kumar, D. (1998) Beneficial effects of electrical stimulation on neuropathic symptoms in diabetes patients. Journal of Foot and Ankle Surgery, 37, 191-194. http://dx.doi.org/10.1016/S1067-2516(98)80109-9

[17] Blum, K., Dinublie, N., Chen, T.J.H., Waite, R.L., Martinez-Pons, M., Callahan, M.F., Smith, T.L., Mengucci, J., Blum, S.H. and Meshkin, B. (2006) H-wave, a nonpharmacologic alternative for the treatment of patients with chronic soft tissue inflammation and neuropathic pain: A preliminary statistical outcome study. Advances in Therapy, 23, 446-455.

[18] Blum, K., Martinez-Pons, M., Dinubile, N.A., Waite, R.L., Schoolfield, J., Blum, S.H., Mengucci, J., Downs, B.W. and Meshkin, B, (2006) H-Wave device, a small muscle fiber stimulator, significantly reduces pain medication, increases function and improves health in 6774 patients with chronic soft tissue injuries and/or neuropathic pain: An extended population observational study. Advances in Therapy, 23, 739-749. http://dx.doi.org/10.1007/BF02850314

[19] Blum, K., Chen, A.L., Chen, T.J., Prihoda, T.J., School- field, J., Dinubile, N., Waite, R.L., Arcuri. V., Kerner, M., Braverman, E.R., Rhoades, P. and Tung, H. (2008) The $\mathrm{H}$-wave ${ }^{\circledR}$ device is an effective and safe non-pharmacological analgesic for chronic pain: A meta-analysis. $A d-$ vances in Therapy, 25, 644-657.

http://dx.doi.org/10.1007/s12325-008-0073-3

[20] Blum, K., Chen, J.H.T. and Ross, B.D. (2005) Innate properties of H-wave device, a small fiber stimulator provides the basis for a paradigm shift of electro-therapeutic treatment of pain with increased functional restoration associated with human neuropathies. Townsend Letter for Doctors and Patients, 1, 101-104.

[21] Blum, K., Chen, A.L., Chen, T.J., Waite, R.L., Downs, B.W., Braverman, E.R., Kerner, M.M., Savarimuthu, S.M. and DiNubile, N. (2009) Repetitive H-wave device stimulation and program induces significant increases in the range of motion of post operative rotator cuff reconstruction in a double-blinded randomized placebo controlled human study. BMC Musculoskeletal Disorders, 10, 132. http://dx.doi.org/10.1186/1471-2474-10-132

[22] Blum, K., Chen, A.L.H., Chen, T.J.H., Downs, B.W., Braverman, E.R., Kerner, M., Savraimuthu, S., Madigan, M., Blum, S.H., Reinl, G. and Dinubile, N. (2010) Healing enhancement of chronic venous stasis ulcers utilizing $\mathrm{H}$-wave ${ }^{\circledR}$ device therapy: A case series. BMC-Cases Journal, 3, 54. http://dx.doi.org/10.1186/1757-1626-3-54

[23] Smith, T.I., Callahan, M.F., Blum, K., DiNubile, N., Chen, T.J.H. and Waite, R.L. (2011) H-wave ${ }^{\circledR}$ effects on blood flow and angiogenesis in longitudinal studies in rats. Journal of Surgical Orthopaedic Advances, 20, 255-259.

[24] Blum, K., Ho, C.K., Chen, A.L., Fulton, M., Fulton, B., Westcott, W.L., Reinl, G., Braverman, E.R., Dinubile, N. and Chen, T.J. (2008) The H-wave ${ }^{\circledR}$ device induces NO dependent augmented microcirculation and angiogenesis, providing both analgesia and tissue healing in sports injuries. Physician and Sportsmedicine, 36, 103-114. http://dx.doi.org/10.3810/psm.2008.12.18

[25] Tsang, B.K., Tajkaushi, K. and Eichhorn, J.H. (1998) Electrical stimulation reduces symptoms of thermal hypersensitivity from injury of sciatic partial ligation in rats. Anesthesia \& Analgesia, 86, S1-S551. http://dx.doi.org/10.1097/00000539-199802001-00322

[26] Flatt, D.W. (1994) Resolution of a double crush syndrome. Journal of Manipulative and Physiological Therapeutics, 17, 395-397.

[27] Mak, A.F., Yu, Y., Kwan, L.P., Sun, L. and Tam, E.W. (2011) Deformation and reperfusion damages and their accumulation in subcutaneous tissues during loading and unloading: A theoretical modeling of deep tissue injuries. Journal of Theoretical Biology, 289, 65-73. http://dx.doi.org/10.1016/j.jtbi.2011.08.022

[28] Szczesny, S.E., Lee, C.S. and Soslowsky, L.J. (2010) Remodeling and repair of orthopedic tissue: Role of mechanical loading and biologics. The American Journal of Orthopedics, 39, 525-530.

[29] Buckwalter, J.A. and Grodzinsky, A.J. (1999) Loading of healing bone, fibrous tissue, and muscle: Implications for orthopedic practice. Journal of the American Academy of Orthopaedic Surgeons, 7, 291-299. 
[30] Gray, M.L., Pizzanelli, A.M., Grodzinsky, A.J. and Lee, R.C. (1988) Mechanical and physicochemical determinants of the chondrocyte biosynthetic response. Journal of Orthopaedic Research, 6, 777-792.

http://dx.doi.org/10.1002/jor.1100060602

[31] Grodzinsky, A.J. (1983) Electromechanical and physicochemical properties of connective tissue. Critical Reviews $^{\mathrm{TM}}$ in Biomedical Engineering, 9, 133-199.

[32] Ingber, D.E. (1997) Tensegrity: The architectural basis of cellular mechanotransduction. Annual Review of Physiology, 59, 575-599.

http://dx.doi.org/10.1146/annurev.physiol.59.1.575

[33] Toma, C.D., Ashkar, S., Gray, M.L., Schaffer, J.L. and Gerstenfeld, L.C. (1997) Signal transduction of mechanical stimuli is dependent on microfilament integrity: Identification of osteopontin as a mechanically induced gene in osteoblasts. Journal of Bone and Mineral Research, 12, 1626-1636.

http://dx.doi.org/10.1359/jbmr.1997.12.10.1626

[34] Guilak, F. (1995) Compression-induced changes in the shape and volume of the chondrocyte nucleus. Journal of Biomechanics, 28, 1529-1541.

http://dx.doi.org/10.1016/0021-9290(95)00100-X

[35] Kim, Y.J., Grodzinsky, A.J. and Plaas, A.H. (1996) Compression of cartilage results in differential effects on biosynthetic pathways for aggrecan, link protein and hyaluronan. Archives of Biochemistry and Biophysics, 328, 331-340. http://dx.doi.org/10.1006/abbi.1996.0181

[36] Buschmann, M.D., Gluzband, Y.A., Grodzinsky, A.J. and Hunziker, E.B. (1995) Mechanical compression modulates matrix biosynthesis in chondrocyte/agarose culture. Journal of Cell Science, 108, 1497-1508.

[37] Quinn, T.M., Grodzinsky, A.J., Buschmann, M.D., Kim, Y.J. and Hunziker, E.B. (1998) Mechanical compression alters proteoglycan deposition and matrix deformation around individual cells in cartilage explants. Journal of Cell Science, 111, 573-583.

[38] Chen, C.S. and Ingber, D.E. (1999) Tensegrity and mechanoregulation: From skeleton to cytoskeleton. Osteoarthritis and Cartilage, 7, 81-94. http://dx.doi.org/10.1053/joca.1998.0164

[39] Smalt, R., Mitchell. F.T., Howard, R.L. and Chambers, T.J. (1997) Mechanotransduction in bone cells: Induction of nitric oxide and prostaglandin synthesis by fluid shear stress, but not by mechanical strain. Advances in Experimental Medicine and Biology, 433, 311-314. http://dx.doi.org/10.1007/978-1-4899-1810-9 66

[40] Eliasson, P., Andersson, T. and Aspenberg, P. (2009) Rat Achilles tendon healing: Mechanical loading and gene expression. Journal of Applied Physiology, 107, 399-407. http://dx.doi.org/10.1152/japplphysiol.91563.2008

[41] Andersson, T., Eliasson, P. and Aspenberg, P. (2009) Tissue memory in healing tendons: Short loading episodes stimulate healing. Journal of Applied Physiology, 107, 417-421. http://dx.doi.org/10.1152/japplphysiol.00414.2009

[42] Nachemson, A. (1985) Recent advances in the treatment of low back pain. International Orthopaedics, 9, 1-10. http://dx.doi.org/10.1007/BF00267031
[43] Nachemson, A. (1975) Towards a better understanding of low-back pain: A review of the mechanics of the lumbar disc. Rheumatology and Rehabilitation, 14, 129-143. http://dx.doi.org/10.1093/rheumatology/14.3.129

[44] Owan, I., Burr, D.B., Turner, C.H., Qiu, J., Tu, Y., Onyia, J.E. and Duncan, R.L. (1997) Mechanotransduction in bone: Osteoblasts are more responsive to fluid forces than mechanical strain. The American Journal of Physiology, 273, C810-C815.

[45] Sah, R.L., Kim, Y.J., Doong, J.Y., Grodzinsky, A.J., Plaas, A.H., Sandy, J.D. (1989) Biosynthetic response of cartilage explants to dynamic compression. Journal of Orthopaedic Research, 7, 619-636. http://dx.doi.org/10.1002/jor.1100070502

[46] Garcia, A.M., Frank, E.H., Grimshaw, P.E. and Grodzinsky, A.J. (1996) Contributions of fluid convection and electrical migration to transport in cartilage: Relevance to loading. Archives of Biochemistry Biophysics, 333, 317325. http://dx.doi.org/10.1006/abbi.1996.0397

[47] Buckwalter, J.A. (1995) Should bone, soft-tissue, and joint injuries be treated with rest or activity? Journal of Orthopaedic Research, 13, 155-156. http://dx.doi.org/10.1002/jor.1100130202

[48] Caplan, A., Carlson, B., Faulkner, J., Fischman, D. and Garrett Jr., W. (1988) Skeletal muscle. In: Woo, S.L.Y. and Buckwalter, J.A., Eds., Injury and Repair of the Musculoskeletal Soft Tissues, American Academy of Orthopaedic Surgeons, Park Ridge, 213-291.

[49] Buckwalter, J.A., Woo, S.L.Y. and Goldberg, V.M. (1993) Soft-tissue aging and musculoskeletal function. The Journal of Bone and Joint Surgery, American Volume, 75, 1533-1548.

[50] National Institutes of Arthritis and Musculoskeletal and Skin Diseases, (2009).

www.niams.nih.gov/Health_Info/Bone/Osteoporosis/defa ult.asp

[51] Uhthoff, H.K. and Jaworski, Z.F. (1978) Bone loss in response to long-term immobilisation. The Journal of Bone and Joint Surgery. British Volume, 60, 420-429.

[52] Burr, D.B., Frederickson, R.G., Pavlinch, C., Sickles, M. and Burkart, S. (1984) Intracast muscle stimulation prevents bone and cartilage deterioration in cast-immobilized rabbits. Clinical Orthopaedics and Related Research, 189, 264-278.

[53] Jordan, K.M. and Cooper, C. (2002) Epidemiology of osteoporosis. Best Practice \& Research Clinical Rheumatology, 16, 795-806. http://dx.doi.org/10.1053/berh.2002.0264

[54] Gennari, L., Merlotti, D., De Paola, V., Martini, G., Nuti, R. (2009) Update on the pharmacogenetics of the vitamin D receptor and osteoporosis. Pharmacogenomics, 10, 417433. http://dx.doi.org/10.2217/14622416.10.3.417

[55] McClung, J.P. and Karl, J.P. (2010) Vitamin D and stress fracture: The contribution of vitamin D receptor gene polymorphisms. Nutrition Reviews, 68, 365-369. http://dx.doi.org/10.1111/j.1753-4887.2010.00295.x

[56] Goodship, A.E., Lanyon, L.E. and McFie, H. (1979) Functional adaptation of bone to increased stress: An experi- 
mental study. The Journal of Bone and Joint Surgery. American Volume, 61, 539-546.

[57] Alvarez-Hernandez, D., Naves-Diaz, M., Gomez-Alonso, C., Coto, E. and Cannata-Andia, J.B. (2008) Tissue-specific effect of VDR gene polymorphisms on the response to calcitriol. Journal of Nephrology, 21, 843-849.

[58] Hou, X., Weiler, M.A., Winger, J.N., Morris, J.R. and Borke, J.L. (2009) Rat model for studying tissue changes induced by the mechanical environment surrounding loaded titanium implants. The International Journal of Oral \& Maxillofacial Implants, 24, 800-807.

[59] Akeson, W.H., Woo, S.L.Y., Amiel, D., Coutts, R.D. and Daniel, D. (1973) The connective tissue response to immobility: Biochemical changes in periarticular connective tissue of the immobilized rabbit knee. Clinical Orthopaedics and Related Research, 93, 356-362. http://dx.doi.org/10.1097/00003086-197306000-00039

[60] Noyes, F.R., DeLucas, J.L. and Torvik, P.J. (1974) Biomechanics of anterior cruciate ligament failure: An analysis of stain-rate sensitivity and mechanisms of failure in primates. The Journal of Bone and Joint Surgery, 56, 236-253.

[61] Laros, G.S., Tipton, C.M. and Cooper, R.R. (1971) Influence of physical activity on ligament insertions in the knees of dogs. The Journal of Bone and Joint Surgery. American Volume, 53, 275-286.

[62] Slack, C., Flint, M.H. and Thompson, B.M. (1984) The effect of tension load on isolated embryonic chick tendons in organ culture. Connective Tissue Research, 12, 229-247. http://dx.doi.org/10.3109/03008208409013685

[63] Woo, S.L.Y., Ritter, M.A., Amiel, D., Sanders, T.M., Gomez, M.A., Kuei, S.C., Garfin, S. R. and Akeson, W.H. (1980) The biomechanical and biochemical properties of swine tendons: Long term effects of exercise on the digital extensors. Connective Tissue Research, 7, 177-183. http://dx.doi.org/10.3109/03008208009152109

[64] Woo, S.L.Y., Wang, C.W., Newton, P.O. and Lyon, R.M. (1990) The response of ligaments to stress deprivation and stress enhancement: Biomechanical studies. In: Daniel, D.M., Akeson, W.H. and O'Connor, J.J., Eds., Knee ligaments: Structure, Function, Injury, and Repair, Raven Press, New York, 122-129.

[65] Dejam, A., Hunter, C.J., Tremonti, C., Pluta, R.M., Hon, Y.Y., Grimes, G., Partovi, K., Pelletier, M.M., Oldfield, E.H., O Cannon, R., Schechter, A.N. and Gladwin, M.T. (2007) Nitrate infusion in humans and nonhuman primates: Endocrine effects, pharmacokinetics, and tolerance formation. Circulation, 116, 1821-1831.

http://dx.doi.org/10.1161/CIRCULATIONAHA.107.712133

[66] Zhou, M.S., Schulman, I.H. and Raij, L. (2004) Nitric oxide, angiotensin 11, and hypertension. Seminars in $\mathrm{Ne}$ phrology, 24, 366-378. http://dx.doi.org/10.1016/j.semnephrol.2004.04.008

[67] Fujii, Y., Guo, Y. and Hussain, S.N. (1985) Regulation of nitric oxide production in response to skeletal muscle activation. Journal of Applied Physiology, 85, 2330-2336.

[68] Pye, D., Palomero, J., Kabayo, T. and Jackson, M.J. (2007) Real-time measurement of nitric oxide in single mature mouse skeletal muscle fibres during contractions.
The Journal of Physiology, 581, 309-318. http://dx.doi.org/10.1113/jphysiol.2006.125930

[69] Ferreira, A.A., Kwasniewski, .F.H., Delani, T.C. Torres, M.G., Silva, M.A., Caparroz-Assef, S.M., Cuman, R.K. and Bersani-Amado, C.A. (2007) Acute immune and non-imune inflammatory response in spontaneously hypertensive rats and normotensive rats. Role of endogenous nitric oxide. Inflammation, 30, 198-204. http://dx.doi.org/10.1007/s10753-007-9037-z

[70] Lizarbe, T.R., Garcia-Roma, C., Tarin, C., Saura, M., Calvo, E., López, J.A, López-Otín, C., Folgueras, A.R., Lamas, S. and Zaragoza, C. (2008) Nitric oxide elicits functional MMP-13 protein tyrosine nitration during wound repair. The FASEB Journal, 22, 3207-3215. http://dx.doi.org/10.1096/fj.07-103804

[71] Fukumura, D., Gohongi, T., Kadambi, A., Izumi, Y., Ang, J., Yun, C.O., Buerk, D.G., Huang, P.L. and Jain, R.K. (2001) Predominant role of endothelial nitric oxide synthase in vascular endothelial growth factor-induced angiogenesis and vascular permeability. Proceedings of the National Academy of Sciences of the United States of America, 98, 2604-2609. http://dx.doi.org/10.1073/pnas.041359198

[72] Williams, R.S. and Annex, B.H. (2004) Plasticity of myocytes and capillaries: A possible coordinating role for VEGF. Circulation Research, 95, 7-8. http://dx.doi.org/10.1161/01.RES.0000136345.81719.37

[73] Hudlicka, O. (1998) Is physiological angiogenesis in skeletal muscle regulated by changes in microcirculation? Microcirculation, 5, 7-23.

[74] Buckwalter, J.A., Einhorn, T.A., Bolander, M.E., Crusess, R.L. (1996) Healing of the musculoskeletal tissues. In: Rockwood Jr., C.A., Green, D.P., Bucholtz, R.W. and Heckman, J.D., Eds., Fractures in Adults, 4th Edition, Lippincott-Raven, Philidolphia, 261-304.

[75] Mathew, S., Arandjelovic, S., Beyer, W.F., Gonias, S.L. and Pizzo, S.V. (2003) Characterization of the interaction between alpha $a_{2}$-macroglobulin and fibroblast growth factor-2: The role of hydrophobic interactions. Biochemical Journal, 374, 123-129. http://dx.doi.org/10.1042/BJ20021655

[76] Proctor, R.A., Textor, J.A., Vann, J.M. and Mosher, D.F. (1985) Role of fibronectin in human monocyte and macrophage bactericidal activity. Infection and Immunity, 47, 629-637.

[77] Mosesson, M.W. (1984) The role of fibronectin in monocyte/macrophage function. Progress in Clinical and Biological Research, 154, 155-175.

[78] Melzack, R. (2005) Evolution of the neuromatrix theory of pain. The Prithvi Raj lecture: Presented at the third world congress of world institute of pain, Barcelona 2004. Pain Practice, 5, 85-94. http://dx.doi.org/10.1111/j.1533-2500.2005.05203.x

[79] Altier, N. and Stewar, J. (1999) The tachykinin NK-1 receptor antagonist, RP-67580, infused into the ventral tegmental area prevents stress-induced analgesia in the formalin test. Physiology \& Behavior, 66, 717-721. http://dx.doi.org/10.1016/S0031-9384(98)00246-7

[80] Altier, N. and Stewart, J. (1999) The role of dopamine in 
the nucleus accumbens in analgesia. Life Sciences, 65, 2269-2287.

http://dx.doi.org/10.1016/S0024-3205(99)00298-2

[81] Morgan, M.J. and Franklin, K.B. (1990) 6-Hydroxydopamine lesions of the ventral tegmentum abolish D-amphetamine and morphine analgesia in the formalin test but not in the tail flick test. Brain Research, 519, 144-149. http://dx.doi.org/10.1016/0006-8993(90)90072-J

[82] Taylor, B.K., Joshi, C. and Uppal, H. (2003) Stimulation of dopamine D2 receptors in the nucleus accumbens inhibits inflammatory pain. Brain Research, 987, 135-143. http://dx.doi.org/10.1016/S0006-8993(03)03318-3

[83] Blum, K., Han, D., Giordano, J., Lohmann, R., Braverman, E.R., Madigan, M.A., Barh, D., Femino, J., Hauser, M., Downs, B.W. and Simpatico, T. (2013) Neurogenetics and nutrigenomics of reward deficiency syndrome (RDS): Stratification of addiction risk and mesolimbic nutrigenomic manipulation of hypodopaminergic function. Chapter-18, In: Barh, D., Dhawan, D. and Ganguly, N.K., Eds., Omics for Personalized Medicine, 1st Edition, Springer, Berlin.

http://www.springer.com/biomed/book/978-81-322-1183-9

[84] Magnusson, J.E. and Fisher, K. (2000) The involvement of dopamine in nociception: The role of $\mathrm{D}_{1}$ and $\mathrm{D}_{2}$ receptors in the dorsolateral striatum. Brain Research, 855, 260-266. http://dx.doi.org/10.1016/S0006-8993(99)02396-3

[85] Hagelberg, N., Martikainen, I.K., Mansikka, H., Hinkka, S., Någren, K., Hietala, J., Scheinin, H. and Pertovaara, A. (2002) Dopamine $\mathrm{D}_{2}$ receptor binding in the human brain is associated with the response to painful stimulation and pain modulatory capacity. Pain, 99, 273-279. http://dx.doi.org/10.1016/S0304-3959(02)00121-5

[86] Hagelberg, N., Kajander, J.K., Någren, K., Hinkka, S., Hietala, J. and Scheinin, H. (2002) Mu-receptor agonism with alfentanil increases striatal dopamine D2 receptor binding in man. Synapse, 45, 25-30. http://dx.doi.org/10.1002/syn.10078

[87] Hagelberg, N., Forssell, H., Rinne, J.O., Scheinin, H., Taiminen, T., Aalto, S., Luutonen, S., Någren, K. and Jääskeläinen, S. (2003) Striatal dopamine $\mathrm{D}_{1}$ and $\mathrm{D}_{2}$ receptors in burning mouth syndrome. Pain, 101, 149-154. http://dx.doi.org/10.1016/S0304-3959(02)00323-8

[88] Chen, T.J., Blum, K., Waite, R.L., Meshkin, B., Schoolfield, J., Downs. B.W., Braverman, E.E., Arcuri, V., Varshavskiy, M., Blum, S.H., Mengucci, J., Reuben, C. and Palomo, T. (2007) Genelnarcotic attenuation program attenuates substance use disorder, a clinical subtype of reward deficiency syndrome. Advances in Therapy, 24, 402-414. http://dx.doi.org/10.1007/BF02849910

[89] Blum, K., Braverman, E.R., Holder, J.M., Lubar, J.F., Monastra, V.J., Miller, D., Lubar, J.O., Chen, T.J. and Comings, D.E. (2000) Reward deficiency syndrome: A biogenetic model for the diagnosis and treatment of impulsive, addictive, and compulsive behaviors. Journal of Psychoactive Drugs, 32, 1-112. http://dx.doi.org/10.1080/02791072.2000.10736099

[90] Elovainio, M., Jokela, M., Kivimäki, M., Pulkki-Råback, L., Lehtimäki, T., Airla, N. and Keltikangas-Järvinen, L. (2007) Genetic variants in the DRD2 gene moderate the relationship between stressful life events and depressive symptoms in adults: Cardiovascular risk in young Finns study. Psychosomatic Medicine, 69, 391-395. http://dx.doi.org/10.1097/psy.0b013e31806bf365

[91] Lawford, B.R., Young, R., Noble, E.P., Kann, B., Ritchie, T. (2006) The D2 dopamine receptor (DRD2) gene is associated with co-morbid depression, anxiety and social dysfunction in untreated veterans with post-traumatic stress disorder. European Psychiatry, 21, 180-185. http://dx.doi.org/10.1016/i.eurpsy.2005.01.006

[92] Dziedzicka-Wasylewska, M. (1996) The effect of imipramine on the amount of mRNA coding for rat dop posttraumatic stress disorder: A study and replication. Biological Psychiatry, 40, 368-372.

[93] Kreek, M.J. and Koob, G.F. (1998) Drug dependence: Stress and dysregulation of brain reward pathways. Drug and Alcohol Dependence, 51, 23-47.

http://dx.doi.org/10.1016/S0376-8716(98)00064-7

[94] Comings, D.E., Muhleman, D. and Gysin, R. (1990) Dopamine D2 receptor (DRD2) gene and susceptibility to Prefrontal cortical dopamine depletion enhances the responsiveness of mesolimbic dopamine neurons to stress. Brain Research, 521, 311-315. http://dx.doi.org/10.1016/0006-8993(90)91557-W

[95] Deutch, A.Y. and Clark, W.A., Roth, R.H. (1997) Amine D2 autoreceptors. European Journal of Pharmacology, 337, 291-296.

[96] Kalivas, P.W., Abhold, R. (1987) Enkephalin release into the ventral tegmental area in response to stress: Modulation of mesocorticolimbic dopamine. Brain Research, 414, 339-348. http://dx.doi.org/10.1016/0006-8993(87)90015-1

[97] Blum, K., Trachtenberg, M.C., Elliott, C.E., Dingler, M.L., Sexton, R.L., Samuels, A.I. and Cataldie, L. (1988) Enkephalinase inhibition and precursor amino acid loading improves inpatient treatment of alcohol and polydrug abusers: Double-blind placebo-controlled study of the nutritional adjunct SAAVE. Alcohol, 5, 481-493. http://dx.doi.org/10.1016/0741-8329(88)90087-0

[98] Hashimoto, T., Hussien, R., Cho, H.S. and Kaufer, D. (2008) Brooks GA: Evidence for the mitochondrial lactate oxidation complex in rat neurons: Demonstration of an essential component of brain lactate shuttles. PLoS One, 3, e2915. http://dx.doi.org/10.1371/journal.pone.0002915

[99] Hashimoto, T. and Brooks, G.A. (2008) Mitochondrial lactate oxidation complex and an adaptive role for lactate production. Medicine \& Science in Sports \& Exercise, 40, 486-494. http://dx.doi.org/10.1249/MSS.0b013e31815fcb04

[100] Nisoli, E., Cozzi, V. and Carruba, M.O. (2008) Amino acids and mitochondrial biogenesis. American Journal of Cardiology, 101, S22-S25. http://dx.doi.org/10.1016/j.amjcard.2008.02.077

[101] Bongrazio, M., Da Silva-Azevedo, L., Bergmann, E.C., Baum, O., Hinz, B., Pries, A.R. and Zakrzewicz, A. (2006) Shear stress modulates the expression of thrombospondin-1 and CD36 in endothelial cells in vitro and during shear stress-induced angiogenesis in vivo. International Journal of Immunopathology \& Pharmacology, 19, 
$35-48$.

[102] Chinsomboon, J., Ruas, J., Gupta, R.K., Thom, R., Shoag, J., Rowe, G.C., Sawada, N., Raghuram, S. and Arany, Z. (2010) The transcriptional coactivator PGC- $1 \alpha$ mediates exercise-induced angiogenesis in skeletal muscle. Proceedings of the National Academy of Sciences of the United States of America, 106, 21401-21406. http://dx.doi.org/10.1073/pnas.0909131106

[103] Akhmetov, I.I., Astranenkova, I.V. and Rogozkin, V.A. (2007) Association of PPARD gene polymorphism with human physical performance. Molekuliarnaia Biologiia, 41, 852-857.

[104] Lo, I.K., Ou, Y., Rattner, J.P., Hart, D.A., Marchuk, L.L., Frank, C.B. and Rattner, J.B. (2002) The cellular networks of normal ovine medial collateral and anterior cruciate ligaments are not accurately recapitulated in scar tissue. Journal of Anatomy, 200, 283-296. http://dx.doi.org/10.1046/j.1469-7580.2002.00024.x

[105] Georgiev, G.P., Vidinov, N.K. and Kinov, P.S. (2010) Histological and ultrastructural evaluation of the early healing of the lateral collateral ligament epiligament tissue in a rat knee model. BMC Musculoskeletal Disorders,

\section{1, 117. http://dx.doi.org/10.1186/1471-2474-11-117}

[106] Ohio Department of Health (2012) Ohio drug poisoning fact sheet: Epidemic of prescription drug overdoses in Ohio.

http://www.healthyohioprogram.org/diseaseprevention/dp oison/drugdata.aspx

[107] Lanier, W.A. (2010) Prescription opioid overdose deaths -Utah, 2008-2009. The 59th Annual Epidemic Intelligence Service Conference, Atlanta, 19-23 April 2010, 1013.

[108] Franklin, G.M., Rahman, E.A., Turner, J.A., Daniell, W.E. and Fulton-Kehoe, D. (2009) Opioid use for chronic low back pain: A prospective, population-based study among injured workers in Washington State, 2002-2005. Clinical Journal of Pain, 25, 743-751. http://dx.doi.org/10.1097/AJP.0b013e3181b01710

[109] Yoast, R., Williams, M.A., Deitchman, S.D. and Champion, H.C. (2001) Report of the council on scientific affairs: Methadone maintenance and needle-exchange programs to reduce the medical and public health conesquences of drug abuse. Journal of Addictive Disease, 20, 15-40. http://dx.doi.org/10.1300/J069v20n02 03

\section{LIST OF ABBREVIATIONS}

ROM: Range of motion;

HWDS: H-Wave ${ }^{\circledR}$ device is stimulation;

NO: Nitric oxide;

MOA: Mechanisms of action;

MCL: Medial collateral ligament;

ACL: Anterior cruciate ligament;

nNOs: Endothelial nitric oxide;

DAF-FM DA: Difluorofluorescein diacetate;

TGFs-beta: Transforming growth factors-beta;

TNF-alpha: Tumor necrosis factor-alpha;

PDGF: Platelet derived growth factor;

IL-6: Interleukin-6;

NGF: Nerve growth factor;

b-FGF: Fibroblast growth factor;

IL-1 beta: Interleukin-1 beta;

VGEF: Vascular endothelial growth factor;

IF: Interferential;

Alpha 2M: Alpha 2-macroglobulin. 